\title{
Major system change through stepwise reconfiguration: A multi-level analysis of the transformation of American factory production $(1850-1930)$
}

\author{
Frank W. Geels* \\ Eindhoven University, Department of Technology Management, IPO 2.10, PO Box 513, \\ 5600 MB Eindhoven, The Netherlands
}

\begin{abstract}
The common view is that major transitions come about through breakthroughs of technological discontinuities. This article proposes gradual and stepwise reconfiguration as an alternative transition pathway. In it, new elements are adopted in the existing socio-technical regime to help solve particular problems. But as more is learned and circumstances change, these elements may trigger further changes in technology, user practice, infrastructure, and policies, eventually altering the basic architecture of the regime. These notions are integrated in a multi-level perspective on transitions and system changes. The resulting reconfiguration perspective is illustrated with a historical case study of the transition from traditional factories to mass production in America (1850-1930). The analysis shows that mass production was the last step in a much longer reconfiguration process involving cumulative changes in machine tools, building materials, materials handling technologies, power generation, and power-distribution technologies. The reconfiguration perspective has wider relevance for other systems that function through the interplay of multiple technologies, e.g., agriculture, retailing, and hospitals.
\end{abstract}

(C) 2006 Elsevier Ltd. All rights reserved.

Keywords: Transition; Reconfiguration; Multi-level perspective; Factory production

${ }^{*}$ Tel.: +31402475414 ; fax +31402444602.

E-mail address: f.w.geels@tm.tue.nl. 


\section{Introduction}

The common view of major system changes involves technological substitution. This view is widely found in the literature on technological discontinuities and breakthrough innovations [1-4]. Many examples have been studied from a business perspective, investigating if and how new firms replace incumbent firms. There are also quantitative long-term studies of substitution processes. For instance, Grübler and Nakićenović [5] made logistic substitution curves for cars versus horses, steamships versus sailing ships, railways versus canals, roads versus railways, coal versus wood, and oil versus coal.

An important element in this technological-substitution view is the concept of dominant design, originating from industrial economics and life-cycle literature [3,6-8]. When a new technology first emerges, there is a variety of design variants and uncertainty. Through learning processes and competition, one design variant becomes dominant, leading to closure and stabilisation. This dominant design forms the basis for consolidation and formation of a new industry, organising other elements around it. Once the gasoline car won out over steam and electric cars, it became the core of a new transport system, with many peripheral technologies organised around it, such as roads, traffic lights, and petrol stations. Users began to organise their lives around the car, using it for commuting, drivein cinema, and remote shopping malls. Many other sectors are also organised around one dominant technology, for example, aviation, where aircraft form the dominant technology; visual home entertainment, where television and video are dominant technologies; telecommunications, where the telephone is the dominant technology-recently supplemented by Internet and e-mail.

Although dominant designs need complementary technologies for their functioning, the literature makes a clear distinction between 'core' and 'peripheral' components $[9,10]$. Artifacts are constructed hierarchically from sub-systems and components, which, in turn, are built from devices. An example of a core component in automobiles is the engine, because the body, brakes, steering, and ignition are all dependent on the engine's characteristics. In this conceptualisation, major changes in artifacts are understood as substitutions for core components, which have cascading effects on peripheral components, changing the product form and architecture. Within watches, for example, "the emergence of the quartz movement had cascading effects on all other watch subsystems as well as manufacturing processes" [11].

This view can be extended to the sectoral level: major system changes take place through substitutions of one core technology for another, accompanied by further changes in peripheral technologies and socio-institutional aspects. The dynamic then has the character of punctuated equilibrium [12]. A system is relatively stable and characterised by incremental innovation until the emergence of a new technological discontinuity. This gives rise to an 'era of ferment,' substitution of the core technology, and settling down to a new stable state $[3,11]$.

Although technological substitution is an important pathway for major system change, this article argues that it is not the only pathway. Technological substitution will be important primarily for sectors organised around a core technology. But there are also sectors that function through the interplay of multiple technologies, which are equally important. Agriculture, for instance, depends on the interactions of pesticides, fertiliser, irrigation and drainage technologies, seed improvement technologies, land-working machines (tractors, plows), and harvesting machines. Another example is the medical 
sector, where a wide range of technologies is used for different diseases and activities (e.g., diagnosis, operation, treatment, care). Yet another example is retailing, where transport, packaging, storing, cooling, scanning, and payment technologies work together. How do major changes take place in such heterogeneous sectors?

To answer this question, the article proposes a stepwise reconfiguration pathway in transitions. Section 2 articulates this pathway, building on the multi-level perspective (MLP) described in a previous article in Technology in Society [13]. This perspective is refined here using insights from actor-network theory, large technical systems (LTSs) theory, and modular innovation. Section 3 illustrates this reconfiguration perspective with a historical case study: the transformation of American factory production (1850-1930). The case study is analysed in Section 4, and conclusions are given in Section 5.

\section{The MLP of a reconfiguration pathway}

The MLP provides a useful framework for understanding system changes and transitions [13-18]. The MLP has three analytical levels: niche, regime and landscape.

The level of socio-technical regimes has three interlinked elements:

(a) A network of actors and social groups, such as engineers, firms, suppliers, universities, users, policy makers, and special-interest groups.

(b) Formal, cognitive, and normative rules that guide the activities of actors. Formal rules refer to regulations, standards and laws; cognitive rules refer to problem agendas, guiding principles, search heuristics; normative rules refer to role relationships in networks and behavioural norms [16].

(c) Material and technical elements (artifacts, machines, infrastructures, materials).

Socio-technical regimes are characterised by path dependence and lock-in, resulting from stabilising mechanisms: incumbent actors have vested interests and may resist change; regulations and standards may stabilise regimes; cognitive routines may blind actors to developments outside their focus; core competencies may turn into 'core rigidities'; existing machines and infrastructures represent sunk investments. Sociotechnical regimes account for dynamic stability of existing systems, meaning that innovation still occurs but is of an incremental nature.

Niches form the level where radical novelties emerge that deviate from the existing regime. Niches may take the form of small-market niches, where selection criteria are different from the existing regime. Or they may have the form of technological niches where resources are provided by public subsidies [19-21]. Niches act as incubators for new technologies, shielding them from mainstream market selection. New technologies need such protection because initially they may have low performance and high price. Niches are important because they provide locations for learning processes (about technology, user preferences, regulation, symbolic meaning, infrastructure, production systems). Niches also provide space to build social networks and constituencies that support innovations.

The socio-technical landscape forms an exogenous environment that influences developments in niches and regimes. The socio-technical landscape usually changes slowly and cannot be changed at will (for example, demographic changes, macro-economics, cultural change). 
Pioneers and innovators typically work on novelties, but these are usually restricted to particular niches. Novelties have a hard time breaking through because the existing regime is usually entrenched. Historical studies have shown that transitions usually occur only when developments at all three levels link up and reinforce each other [13,17,22,23]. Typically, a radical innovation first emerges in a small niche where it can develop and stabilise. Breakthrough and broader diffusion depend on three kinds of processes: (1) external landscape changes that create pressure on the regime, (2) frictions and tensions in the regime that weaken the stability and form a window of opportunity for change, and (3) price/performance improvements in the niche innovation and support from powerful social groups. In this set of circumstances, a new technology may enter mainstream markets and compete with an existing technology. If the new technology wins, the ensuing replacement is accompanied by changes in regulations, infrastructure, user practices, and industry structures (see Fig. 1).

An important aspect of the MLP is to do away with simple causality in transitions and system transformation. There is no simple cause or driver. Instead, there are processes at multiple dimensions and levels simultaneously. System transformations come about when these processes link up and reinforce each other, known as 'circular causality.'

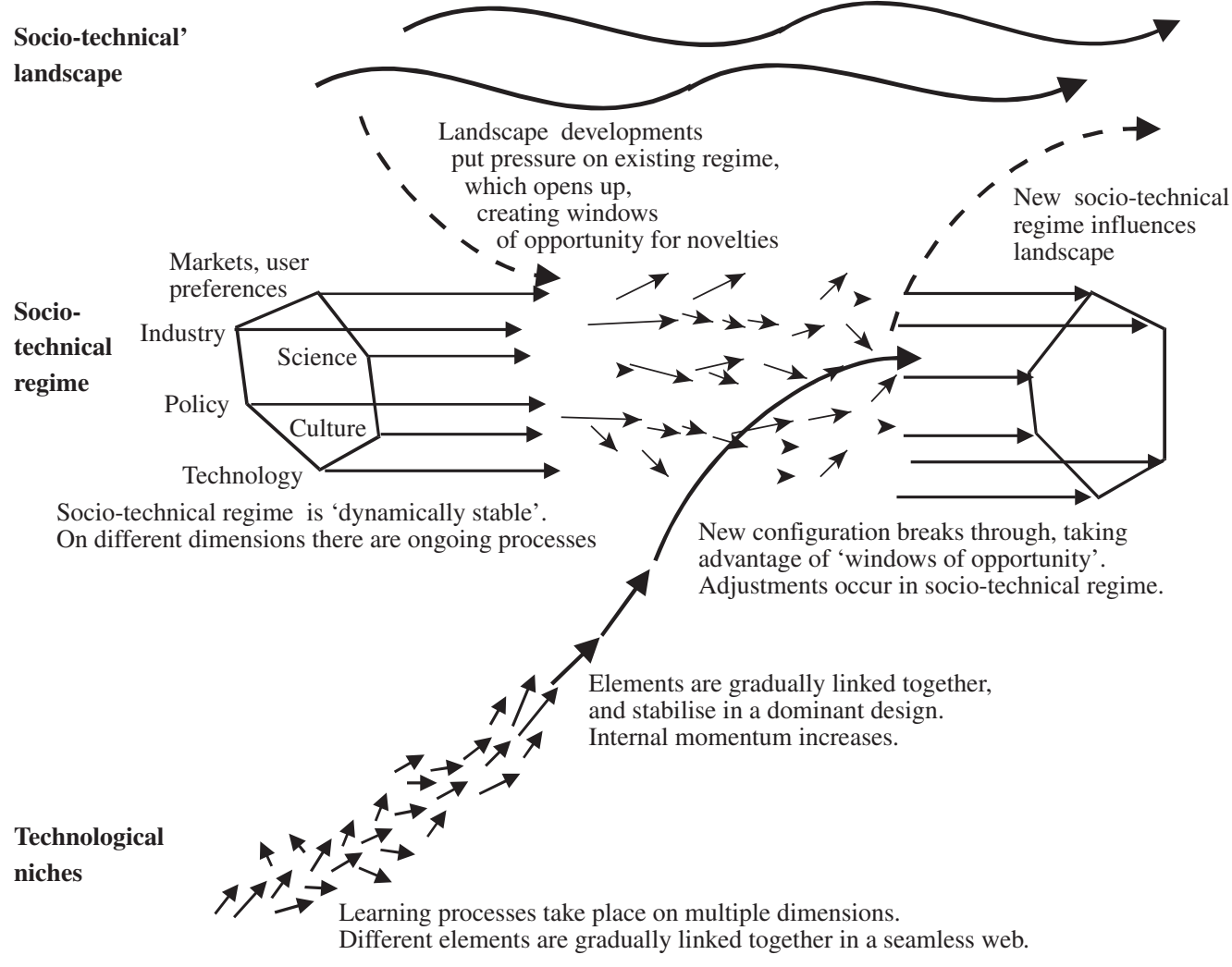

Fig. 1. A dynamic multi-level perspective on system innovations. Source: [15, p. 1263] 
Although the MLP has proved useful for understanding transitions, it also has a substitution bias, as Fig. 1 illustrates, where a major innovation breaks through and replaces the existing regime. To make the MLP useful for understanding major changes in complex systems without dominant technology, adjustments need to be made. Inspiration for these adjustments comes from three sources: LTSs theory, actor-network theory, and the literature on modular innovation.

In LTSs theory, Hughes [24] developed the metaphor of a 'seamless web' to indicate how physical artifacts, organisations (e.g., manufacturing firms, investment banks, R\&D laboratories), natural resources, scientific elements (e.g., books, articles), legislative artifacts (e.g., laws) are combined to achieve functionalities. Although this emphasis on socio-technical linkages is useful, a drawback is that the LTS approach mainly focuses on the emergence of LTSs, such as electricity networks, railroad networks, telephone systems, and the Internet. It says little about transitions from one LTS to another. Nevertheless, two authors have developed useful concepts of system change. Von Meier [25] believes that the integration of 'supple technologies' (gas turbines, photovoltaic solar cells, wind turbines) into the existing electricity system may stimulate gradual transformations from within. These technologies can be first introduced in small market niches to solve specific problems in an electricity system (for instance, demand for modular power sources that have short lead times and can be easily upscaled). Once these technologies are introduced, they may open up new possibilities because of particular technical and functional characteristics (more flexibility, decentralised operation). When these technologies take on a dynamic of their own (because of cost reductions and technical advances), they may lead to further transformations in grid operation and control, planning, legal dimensions, and ownership. Many incremental changes thus can add up to major reconfigurations.

Further inspiration comes from Grundmann [26] who sketches a possible future transformation of the transport system. He argues that existing and emerging technologies could interlock to produce 'new combinations' on the level of transport systems. The main dynamic is not substitution of one transport mode for another but diversification of transportation modes, which together lead to a new inter-modal system. In his fictional scenario, there are small, light-weight electric cars for short distances, traditional sedan automobiles (petrol or hydrogen) for long distances, and transfer points where drivers can park their car and switch to public transport systems. Electronic media (e.g., radio data systems) could be used to link different traffic systems to each other and guide traffic flows between them. Information and communication technologies could be used for electronic road management to give drivers better information about traffic flows and available parking space. If these technologies are combined in creative ways, they may result in a transformation of the transport system. This fictional scenario is interesting because of the kind of dynamic it highlights. It does not emphasise substitution but gradual transformation and reconfiguration. These concepts could be integrated into a more comprehensive perspective on transitions and be better empirically illustrated, as the fictional scenarios contain too many aspects of wishful thinking.

Similar notions about change dynamics can be found in actor-network theory, often with a micro-focus. In actor-network theory, linkages between social and technical elements are taken as a basic ontology. New technologies never emerge in an empty world, but rather in a world already made up of existing networks. If we introduce a new technology in an existing network, or substitute an existing element, it does not leave the network unaffected. Instead, it may trigger further changes in the network. Latour [27] gives the 
example of the late 19th-century Kodak camera, in which the wet plates of the camera were replaced by dry collodion film. This was not merely a technical substitution, but triggered further changes:

... capitalists are replaced by other capitalists, and above all, average consumers replaced professional-amateurs .... A successful innovation requires the simultaneous building of a new object (the Kodak camera) and of a new market (the mass market). What is remarkable in the story is that you are faced with ... shifting assemblies of associations and substitutions" [emphasis added] ([27], p. 113)

The idea of "shifting assemblies of associations" implies that the introduction of a new artifact into an existing network may trigger further changes and transformations. On a micro-level, Latour [28] described how relations between a hotel manager and his guests change when a bulky weight is added to the key. ${ }^{1}$ The notions of shifting assemblies of associations, and reconfigurations in socio-technical networks, are interesting but applied mainly at the micro-level of local practice. What we seek for this article is actor-network theory at a meso-level.

Some of these ideas about change dynamics can also be found in the literature on modular and architectural innovation. Complex technological products and systems are made up of many components and subsystems that are interconnected and organised in particular product architectures. This means that product innovation can be directed at components, architectures, or combinations of both. Modular innovation means that components are improved or replaced without affecting other components or the product architecture. Architectural innovation means that the components stay the same but the linkages between them are changed. Radical innovation involves changes in both components and architecture (see Table 1).

In technology management, there has been much attention given to modular innovation because it enables distribution of labour, specialisation, and flexible innovation [29,30]. But sometimes change may begin as modular innovation and subsequently trigger adjustments in other components and change the product architecture. This happens especially when components are drastically changed or improved. Such cascade dynamics may be unforeseen. Henderson and Clark [9] give the example of the jet engine, which began as a straightforward component substitution (replacing the piston engine) but eventually influenced the rest of the airplane (e.g., swept-back wings, larger size).

The ideas from these literature sources can be incorporated into the MLP by changing the original assumptions about relationships between niche innovation and regime. One assumption was that niche innovations always have a negative, competitive relationship with the existing regime and aim to overthrow it. But niche innovations can also be symbiotic, and become adopted in the regime to solve small problems or fulfill additional functions. So niche innovations may form add-ons to help improve the regime's functioning. Or they may replace particular components of the regime without overthrowing it. A second assumption was the focus on the emergence and breakthrough of one niche innovation. But, of course, niches can also act as locations where multiple new elements are generated.

\footnotetext{
${ }^{1}$ Initially, the hotel manager had to ask guests to leave the key at the hotel desk when they went out, something they often forgot. When a weight was added to the key, guests were aware of carrying the key around and left the key at the desk on their own initiative.
} 
Table 1

A framework of innovations

\begin{tabular}{lll}
\hline & Components reinforced & Components overturned \\
\hline $\begin{array}{l}\text { Architecture unchanged (linkages between components) } \\
\text { Architecture changed }\end{array}$ & $\begin{array}{l}\text { Incremental innovation } \\
\text { Architectural innovation }\end{array}$ & $\begin{array}{l}\text { Modular innovation } \\
\text { Radical innovation }\end{array}$ \\
\hline
\end{tabular}

Source: [9, p. 12].

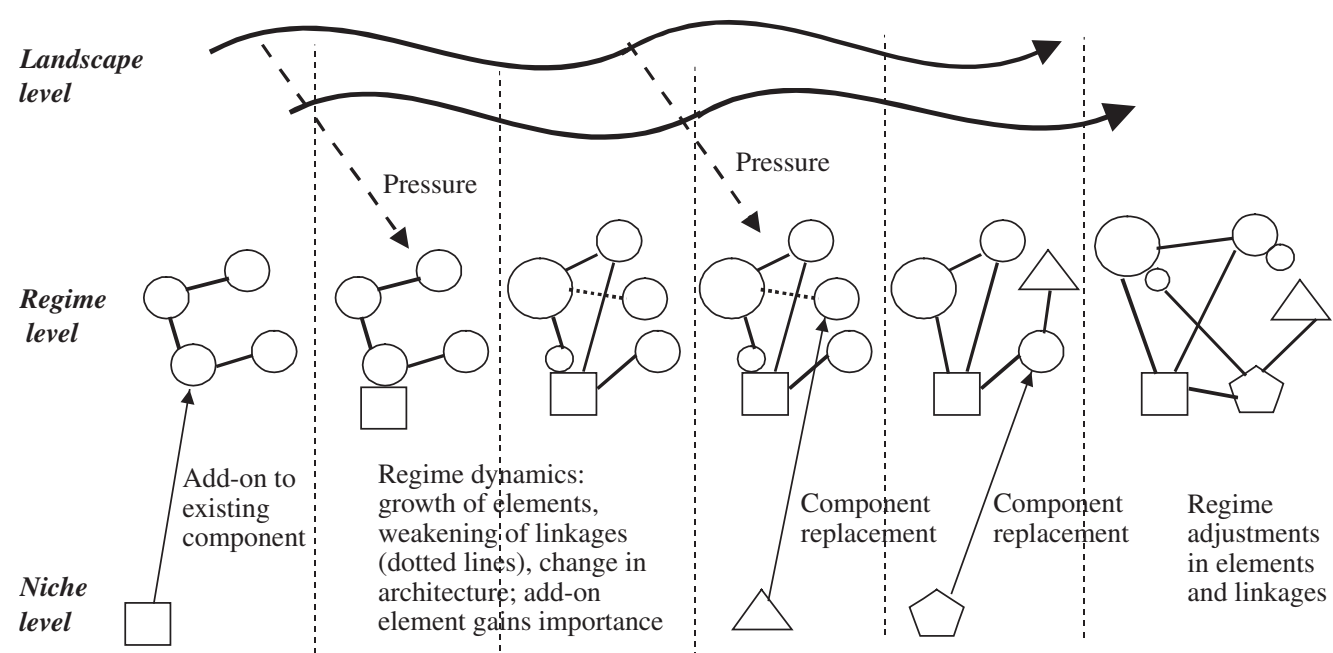

Fig. 2. Reconfiguration route in multi-level perspective.

The combination of these two assumptions leads to a reconfiguration pathway within the MLP. In this pathway, transitions are not caused by the breakthrough of one technology, but by sequences of component innovations. These new components are initially developed in niches at the fringe of the regime and are subsequently adopted in the regime to solve particular small problems. This may take the form of an add-on to the existing system or a component replacement initially as modular innovation. According to actor-network theory, the integration of new elements in the existing regime may also trigger wider changes and affect other technical trajectories, policies, or user preferences. Gradually new elements may be improved, or actors may learn more about other applications. Developments at the landscape level may also create windows of opportunity for further change. These changes may, in turn, create windows of opportunity for the adoption of more niche elements. Through cascade effects and shifting assemblies of association, the initial modular innovation may gradually change the architecture. Thus, over time, many small stepwise changes can add up to major reconfigurations. The cumulative result is radical innovation and system change. So the combination of ongoing regime developments, adoption of new niche elements, and landscape pressure may over time result in major system changes. Fig. 2 represents this multi-level reconfiguration pathway. Particularly in socio-technical systems with multiple technologies, such a stepwise reconfiguration is likely. 


\section{Case study: the transformation of American factory production (1850-1930)}

To illustrate stepwise reconfiguration, this section describes a historical case study - the transformation of American factory production (1850-1930). Factory production is a complex socio-technical system, with many technical elements, including machine tools, power sources, power distribution to machine tools, factory building, materials handling technologies, and lighting technologies. Fig. 3 illustrates these elements and their relationships. Social elements are also important, e.g., organisation of labour, government regulations, insurance rules, and cultural concerns about the survival of small firms.

The elements in the socio-technical factory system are (re)produced and maintained by a range of social groups: industrial engineers, factory owners, supervisors, labourers, machine-tool manufacturers, energy suppliers, and manufacturers of steam engines and electric motors. These groups interact during the transformation.

The case study will show that the transition from traditional factories to mass production was a gradual reconfiguration process involving changes in all aspects of the socio-technical system. The case study focuses on the United States because this is where the transition first occurred. Furthermore, the case gives more attention to product and assembly industries than to process industries. Another choice is the focus on big factories. Although small artisan workshops are touched on, they are given less attention. Historians may criticise this choice, pointing to recent historical contributions, which argue that small workshops followed an alternative modernisation path based on specialty production and flexible knowledge networks [31-33]. But it is not my aim to add to this historical debate. This article reduces historical complexity in order to discover particular patterns and pathways. I acknowledge a disadvantage: that the resulting story may seem teleological,

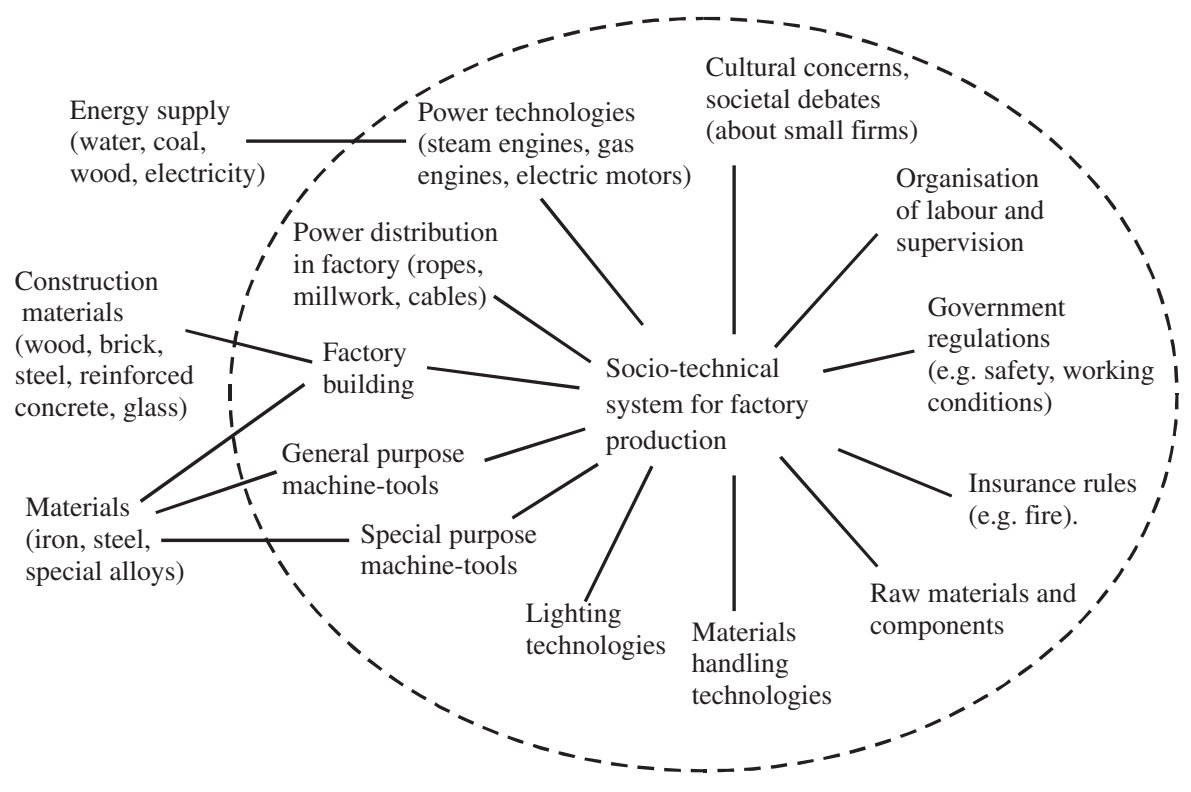

Fig. 3. Socio-technical system in factory production. 
suggesting that mass production was the only possible way to modernise. This neglects historical variety, exceptions, and alternatives. Nevertheless, I make the choice to focus on big factories because this article has theoretical, not historical, aims.

Many scholars have written about the transformation of factory production from a management perspective, looking at the separation of ownership and management, the emergence of a hierarchical organisation structure, interactions between top executives, middle management, and labourers [34]. This article does not pay much attention to such managerial and organisational issues, but focuses instead on the workfloor where real factory production took place. Mass production has also been investigated in economic history, often with a focus on the role of electricity as a general-purpose technology [35-38]. An important question in this literature is the productivity paradox, that is, why substantial productivity improvements occurred one or two decades after the adoption of electric motors. This literature is more interested in the effects of the transition than in the underlying dynamics, which are the focus of this article. Another relevent literature is history of technology [39,40], which has a strong empirical focus but uses little explicit theory. I use this literature as an important source of data, but I add a conceptual perspective to illustrate the reconfiguration pathway. The aim of this article is not to present new empirical findings, but to bring together empirical material from different sources and analyse it to find patterns and pathways.

The case study is divided into four time periods, and within each period I discuss developments at the landscape, regime, and niche levels.

\subsection{Expansion and problems in traditional factories (1850-1880)}

\subsubsection{Landscape-level developments}

An important characteristic of the American macro-landscape was a shortage of skilled artisan labour, which led to higher wages than in Europe. This gave management added incentive for greater mechanisation and the use of unskilled labour, which was available because of the abundant inflow of immigrants [41]. Another landscape development was the construction of a national rail network in the 1840s and 1850s, which facilitated the transportation of coal to cities, lowered its price, and stimulated a shift from waterwheels to steam engines. Rail also created a national market that stimulated economies of scale in production. Population more than tripled between 1850 and 1900, and income was spread more evenly than in Britain, favouring the production of standardised goods. This also stimulated economies of scale in production. These market incentives and new process technologies (large-scale furnaces and oil refineries) promoted the emergence of large-scale corporations in certain industries (e.g., steel, oil, metals). The years following the Civil War (1861-1865) saw the rise of big business, with industry growing at a rapid pace. In 1865, the annual production of goods was estimated at $\$ 2$ billion; by 1900 it stood at $\$ 13$ billion, transforming the US from fourth to first in the world in terms of productivity [42]. Public opinion was ambivalent about the rise of large industries: on the one hand admiring ruthless entrepreneurs, but on the other hand concerned that large industries would overshadow small, artisan workshops. Until the late nineteenth century, most manufacturing took place in small workshops that provided more jobs than did large industry. Many journalists, statesmen, and economists sympathised with small workshops and establishments [43]. 


\subsubsection{Regime-level developments}

In the regime of factory production, an important development was the shift from water to steam power, facilitated by decreasing coal prices. Steam powered all kinds of machines, further enabling the mechanisation process. Mechanisation, in turn, was related to the division of labour. Breaking a job into smaller and simpler tasks made it possible to use semi- and unskilled labour to operate machine tools.

Steam engines were first introduced in the textiles and metalworking industries in the 1830 s and 1840s. To accommodate the growing numbers of machines and workers, a new kind of building was created - the textile mill, a multi-story, long, narrow building [44]. The structure of mill buildings was constrained by the energy, lighting and building technologies of the time. Buildings had multiple stories because moving goods vertically by cranes and elevators was more convenient than moving them horizontally by carts or with animals. Power was mechanically distributed from a central power source (water wheel or steam engine) to individual machines throughout the mill by a series of shafts and belts, the so-called 'millwork' or direct-drive system (see Fig. 4). The central power source turned line shafts via pulleys and leather belts. These line shafts were suspended from the ceiling and extended the entire length of each floor of a factory. Production machinery was arranged in rows parallel to the line shafts and powered by belts and pulleys. "The entire network of line shafts and countershafts rotated continuously, from the time the steam engine was started up in the morning until it was shut down at night, no matter how many machines were actually being used" ([46], p. 352). Mill buildings were long, because machines were placed parallel to the line shaft. But buildings could not be too long because

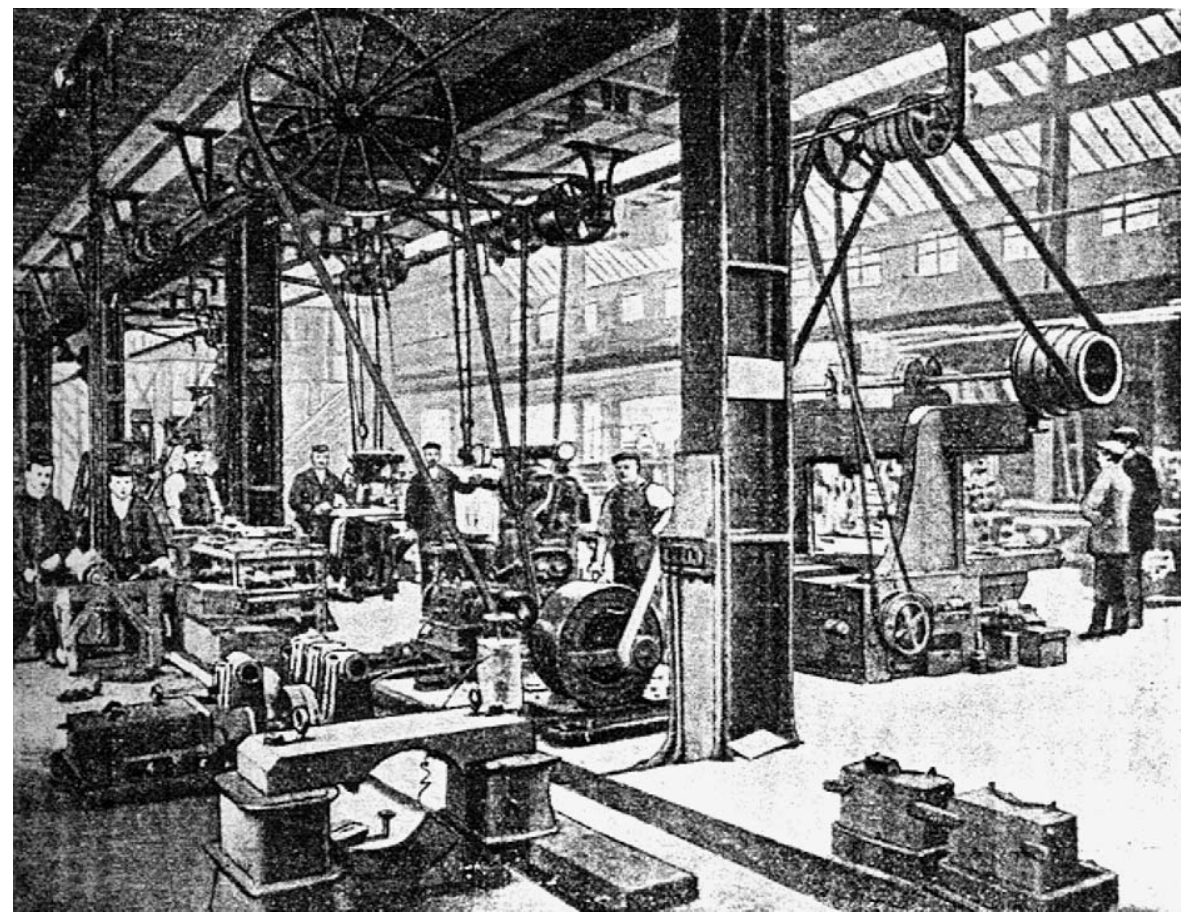

Fig. 4. Millwork (shafts, belts) in 19th century factories. Source: [45, p. 544] 
of power losses through friction in line shafts. Hence, machines were placed on different stories and powered by a vertical shaft that extended upward through holes in the floor. Mill buildings were narrow, about 30 feet in width, because they mainly relied on natural light [40]. In a wide building, the centre section of the shop floor typically did not receive enough light. The windows could not be large because that undermined the strength of outside walls, which consisted of wood and bricks.

An important regime-level event was the development and use of machine tools, which occurred first in textiles, metalworking, and firearms [40]. The textile industry provided space for the development of spinning and weaving machines. Metalworking provided space for the development of heavy, general-purpose machine tools (lathes, planers, boring machines). And arms-making was the industry where lighter, more specialised machine tools were developed (turret lathes, milling machines, precision grinders). The armsmaking industry also made a unique contribution to mechanisation in the 1830s and 1840s: precision manufacturing of interchangeable parts using special-purpose machine tools. The Army was interested in firearms with interchangeable parts because they could be easily repaired if parts broke down in battle. Hence, the United States Ordnance Department was willing to expend an "extraordinary sum of money over a 40- or 50-year period" [39, p. 4] to develop and refine the system of interchangeable parts and special-purpose machine tools. The firearms industry was also instrumental in the development of a wide range of tools and accessories for the production of precision metal parts: jigs, fixtures, taps and gauges. Two particularly versatile machine tools were the milling machine and the turret lathe [47]. Once the turret lathe was developed for arms production, it was adapted and modified in the 1850 s and 1860 s to produce components for sewing machines, watches, typewriters, locomotives, and bicycles. Because metalworking involved a relatively small number of operations (turning, boring, drilling, milling, planning, grinding, polishing), machine-tool innovations in one sector could easily spill over to other sectors, creating positive feedback. From the 1850s through the 1870s, the sewing-machine industry provided space for further machine-tool innovations, such as precision gear-cutting machines, precision grinding of hardened steel parts, and the universal milling machine [47]. These machine tools were later used in bicycle and automobile production.

There were several problems in the factory production regime, which influenced the direction of innovation. Labour costs were one problem, creating incentives for mechanisation. A second problem in mill factories was insufficient lighting due to small windows [44]. A third problem was the millwork in factories, which created inflexibility. Machines could not be organised according to the sequence of work operations because they were fixed to the line shafts. Furthermore, machines could not be powered individually because the entire network of line shafts and countershafts rotated continuously. Millwork also created a lot of dust, made considerable noise, and many workers lost fingers or hands in the machinery. Millwork was also troublesome to repair because it meant the entire apparatus had to be stopped. Another problem was friction and power loss, especially in large factories. Hence, great attention was given to the development of new mineral-based lubricants and to maintenance. But routine lubrication and adjustment of shafts, pulleys, and belts, added to labour costs.

Besides these problems in factories, there was also a problem in small workplaces (e.g., shoemakers, tailors, blacksmiths, machinists, milliners, wheelwrights, bakers) and small industries (clothing, printers and publishers, beverages, cabinet makers). For these places, steam engines were too large and produced too much power for the few machines 
being used, such as a saw or grindstone. Furthermore, the steam engine and boiler occupied space and required fuel storage, water supply, and some degree of maintenance skill. As more machine tools became available, small workplaces experienced a growing need for power in amounts of one to five horsepower, or even fractional horsepower (less than one horsepower), to power a sewing machine.

\subsubsection{Niche-level developments}

In response to these regime problems, many innovations were pioneered in niches. In some processing industries (e.g. canning, meat packing, steel making), innovations in materials handling were pioneered. In the meat industry, for instance, moving a carcass around the plant by hand was difficult and inefficient. In the 1850s and 1860s, experiments were tried with overhead conveyors, endless chains, and moving benches, to eliminate manual handling of carcasses [40]. On this 'disassembly line,' the carcass was cut in pieces as it moved through the factory. This was one of the first steps toward continuous movement in materials handling.

In response to power-distribution problems, several innovations were pioneered in specific niches. One innovation was steam distribution, which received much attention in the 1860s and 1870s. Steam was generated centrally and then distributed via insulated steam lines to decentralised steam engines. This option was tried in some businesses but found to be unsatisfactory, mainly because of high heat losses in steam lines [48]. Another innovation was hydraulic power transmission, which distributed compressed water by pipes to the point of use. This was used from 1850 to 1900 , for instance, to power hydraulic cranes that handled cargo in seaports [48]. The hydraulic system was extended to lock gates, swing bridges, railway yards, and was also found in industrial applications such as forging and pressing. But hydraulic power was less effective in cold climates; it was also difficult to use high flow velocities in pipes because of turbulent friction losses. So the problem of power distribution in factories remained unsolved.

In response to the needs of small power users, several radically new engines were developed in the 1860 s and 1870s, including hot-air engines, internal combustion gas engines, hydraulic motors, and aerial motors. These alternative power techniques were sources of fascination and hope, exhibited at international fairs and discussed in popular and technical journals. The gas engine was the most successful, selling in substantial numbers in the 1870s and 1880s, especially the Otto and Langen engine (1867) and the Otto 'Silent' (1876). The gas engine was more flexible and compact than steam engines, and could easily be switched on and off. Gas engines could utilise the gas infrastructure that already existed for gas lighting.

Another innovation was electricity, which emerged in the late eighteenth century as a topic of scientific interest. In 1821, Faraday demonstrated the possibility of producing continuous rotary motion by electromagnetism. He devised a tiny, toylike electric motor that produced a circular motion. The practical use of electric motors remained limited because of their low efficiency and heavy batteries. The Gramme dynamo (1869) increased the efficiency of converting electrical energy into mechanical energy. By 1874, Gramme had experimental, electricity-driven machinery in his Paris factory [49]. Small batterydriven motors emerged during the 1870s for light power uses, such as operating dentists' drills, jewelers' lathes, small fans, and church organs [48]. These minimotors (often no more than 0.1 horsepower) were little more than curiosities. But electricity could also be 
used for other purposes. In the 1830s it was used in telegraphy, then in the 1850s in electrometallurgy, and in the 1870 s in electric arc lights.

\subsection{Intensification of factory problems and adoption of new elements (1880-1900)}

\subsubsection{Landscape-level developments}

The last decades of the nineteenth century were characterised by several important landscape-level changes. One was the continued expansion of large industrial enterprises in industries such as chemicals, petroleum, rubber, electrical equipment, steel, and transportation equipment. These industries build big factories that covered large areas, adding to the problems with power distribution. In reaction to the rise of big business, there was ongoing concern for the survival of small workshops, which was seen as the moral backbone of the country. But in the liberal laissez-faire climate, politicians refrained from interfering in the economy.

Another macro-development was the rise of engineers as a new professional group. Engineers were seen as progressive, and they enjoyed societal esteem and respect for their contributions to public works. In the late 1880 s, industrial engineers began to establish themselves as professional sub-group, subsequently establishing university teaching programs, then in 1917 the professional Society of Industrial Engineers [40].

Another major landscape-level development was the electrification of society, which gathered speed. In 1882 Thomas Edison opened the first central-station electricity network to support electric lighting with improved incandescent light bulbs. This was followed by electric trams in the late 1880s, and the early use of electric motors in manufacturing in the 1890s. The electrification of society was surrounded by great cultural enthusiasm, expressed at exhibitions and in newspapers.

\subsubsection{Regime-level developments}

Two important developments in the regime of factory production were the proliferation of machine tools and an expanding scale of operations.

The development and diffusion of new machine tools accelerated in the $1880 \mathrm{~s}$. The bicycle industry played an important role because bicycles were assembled from many parts. In early bicycle factories almost every part (pedals, crank hangers, steering heads, joints, forks, hubs, spokes, gear) was forged in the company's drop-forging room. These parts were then moved to the machining room to be finished by grinding, turning, milling, drilling, and other metal-removing operations. This was a time-consuming process that involved many operations and machine tools (lathe, drill press, milling machine, casting machines). The process of making parts was revolutionised in the 1890 s by sheet-metal stamping which allowed parts to be stamped directly out of sheet metal, thereby reducing labour intensity and increasing precision [39]. The more-precise parts sped up bicycle assembly since each part fitted precisely. This demonstrated how interchangeable parts, produced by special-purpose machine tools, could speed up assembly - a lesson Henry Ford would later take to heart.

A second development was the growing scale of factories, which intensified a range of problems. One problem was materials handling. Components and half-finished products were moved by hand, wheelbarrow, or horse-drawn wagon between work stations and machine tools, to keep machine operators well supplied with parts and materials. As the size of factories increased and as more machine tools were introduced, this method of 
materials handling grew increasingly problematic and costly. A second problem was the distribution of power. Power losses through friction increased as factories expanded. Industrial engineers investigated, measured, and discussed the problem. A report in 1885, covering some 50 textile mills, estimated that $25-40 \%$ of power was consumed by friction in the engine and millwork [48]. Millwork was also problematic because of its inflexibility in the arrangement of machine tools. As the number of machine tools increased, millwork increasingly became a strait-jacket, constraining the size and layout of factories.

Other ongoing problems were insufficient lighting, and the lack of an appropriate power source for small power users. Although gas engines, hot-air engines, hydraulic motors, and aerial motors alleviated the problem to some extent, they did not solve it. The lack of an appropriate power source hindered small businesses from taking advantage of the increasing availability of machine tools.

\subsubsection{Adoption and diffusion of niche innovations in the regime}

In response to the regime problems, innovations from the earlier period were further developed and adopted. With regard to materials handling, innovations from the previous period gathered pace. More experiments were done with a range of techniques, such as conveyor systems that relied on gravity, electric cranes, monorails, and internal railways for heavy materials [40]. In particular, electric-powered cranes attached to the ceiling improved the ability to handle heavy equipment and materials [50]. But such a crane required a clear space without interference from shaft and belts, thus putting more pressure on the existing millwork. Electric cranes, monorails, and internal railways helped to alleviate the materials handling problem to some extent but did not solve it. In processing industries, materials handling technologies increasingly replaced manual handling. While (dis)assembly lines were pioneered in the meat packing industry, innovations with continuous movement continued in several market niches, such as cigarette making, furniture making, cloth, grain products, soap, and canned foods [42]. The can-making industry was one of the first to combine special-purpose machinery with a conveyor system (see Fig. 5).

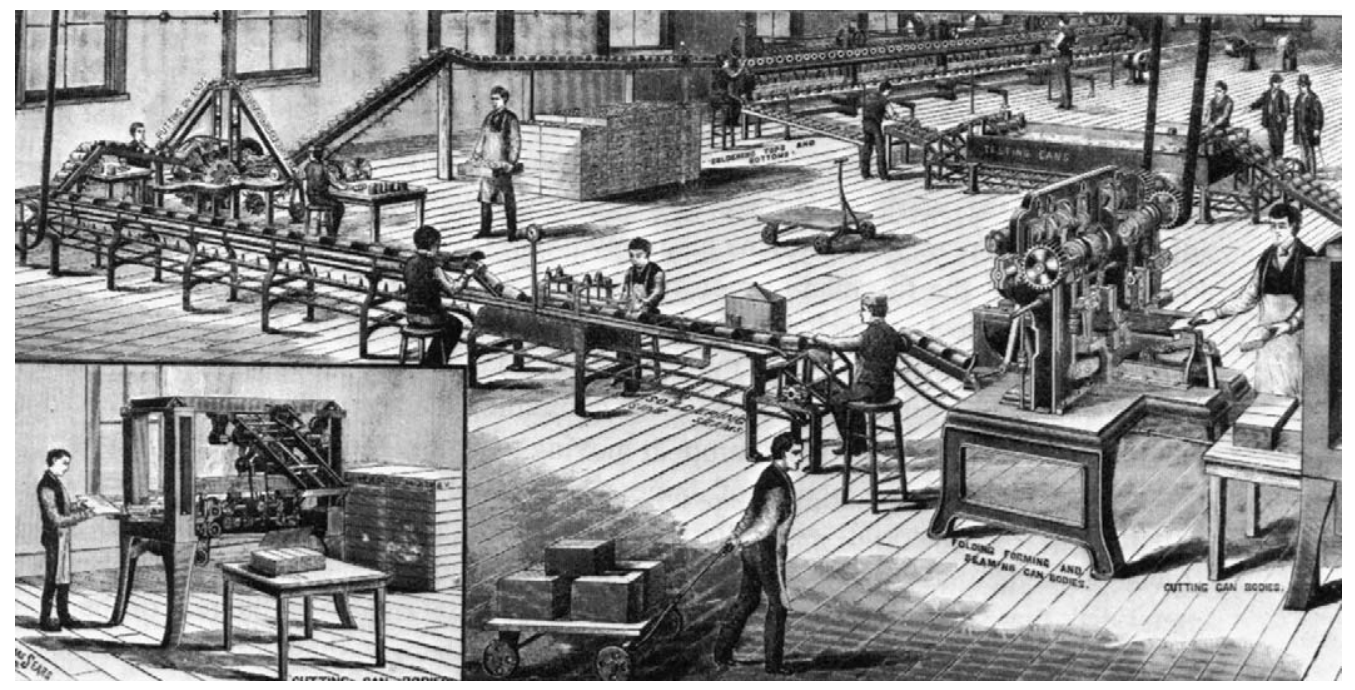

Fig. 5. Can-making machinery, 1885 from the American Machinist, July 14, 1885. Source: [39, p. 243] 
The problem of insufficient lighting provided a window of opportunity for electricity. In some factories, electric light bulbs were hung above individual machines, but the bulbs were of low wattage and had a limited lighting range. Furthermore, girders, shafts, belts, and cranes were obstacles that hindered the diffusion of light. With electric light, factories built competencies with electric technologies (e.g., generator, bulbs, wires, metres). Factories also created internal electrical circuits [50]. Electric motors would later build upon these developments. So, in retrospect, electric light functioned as a stepping-stone for electric motors.

There were also new materials that entered the regime and contributed to improvements in machines and buildings. Steel influenced factory production in many ways. Between 1870 and 1900, steel grew from a minor industry to a dominant manufacturing enterprise. There were numerous positive technical connections between steel, electricity, and machine tools. The electric furnace enabled the production of steel with less contamination, which was essential to the production of high-quality alloy steel [51]. High-strength, heatresistant steel alloys were used in electricity generation equipment, allowing higher temperatures and pressures and leading to greater fuel economy and lower costs [51]. Hard alloy steel helped create machine tools with harder cutting edges and greater precision [52]. High-speed steel improved the ability of a cutting tool to maintain its hardness at high temperatures. The new materials thus resulted in improvements in the accuracy and speed of machine tools. These improved machine tools made it possible to shape and form steel more efficiently, for example, sheet metal stamping techniques and electric welding. Because of its strength, steel also influenced the shape of buildings. Those built with traditional materials could not cover large spaces and required support pillars at intervals. Steel beams could span longer distances, which allowed the creation of large open areas, saving space and creating more freedom to arrange machines. Steel also played a role in a new building material-reinforced concrete, which used implanted steel bars inside concrete structures. Between 1880 and 1900, framing buildings with reinforced-concrete columns and beams became a practical reality.

An important development in social networks was the emergence of industrial engineers. The regime problems and new innovations provided a window of opportunity for this new social group to position itself as problem solver and change agent. The industrial engineer looked at the design of individual machines as well as the layout and organisation of entire factories. While the factory building had previously simply been a shell to provide protection from the weather, industrial engineers approached it as a system, the 'master machine' [40]. Their guiding principle was to make entire factories more rational and efficient. Industrial engineers became spokespersons for redesigning the factory using new materials such as steel, reinforced concrete, and specialised machine tools. Industrial engineers also focused on workers, whom they saw as part of the 'machine'. Taylor developed his 'scientific management' using time studies and financial incentives to increased workers' speed. He also advocated further distribution of labour and more use of special-purpose machine tools, since this made it possible to replace expensive craftsmen with cheaper, unskilled labourers.

\subsubsection{Niche developments in power sources}

The new power sources were first used in small market niches to meet the power needs of small workshops. The internal combustion gas engine experienced substantial market growth in the 1880 s and 1890 s, it was widely believed that it could meet the needs of small 
power users [53]. But improvements in the electric motor made it a strong rival of gas engines. In the early 1880 s, very small or 'fractional horsepower' electric motors were used by small power users for sewing machines, fans, and the like [50]. But the use of electric motors by small power users was hindered in the 1880 s by the limited availability of electricity. While large power users could use their existing steam engines to produce electricity, small power users were dependent on utilities. But electricity grids were not (yet) widely available. Furthermore, electric power was expensive, especially for small power users. Because no reliable electric metre was yet available, tariffs were based on flat rates rather than on actual power consumption [48]. On top of that, electric motors were still expensive because they were handmade.

The cultural enthusiasm for electricity provided a stimulating context for all kinds of experiments and demonstrations with electric motors, often at exhibitions and shows. In 1879, Siemens showed the technical feasibility of powering trams with an electric motor at the Industrial Exhibition in Berlin. At the first International Electrical Exhibition in Paris in 1881, it was demonstrated that electric motors could, in principle, power machine tools such as lathes, a drill, and a printing press [48]. But because electric motors were still weak and cumbersome, these were experiments rather than marketable options.

Beyond small power users, another niche for electric motors was formed by 'additional functions' in large factories. One additional function was to power fans, which contributed to clean air and dust removal [48]. A second additional function was the electric crane, which did much of the heavy lifting, alleviating problems in materials handling in the existing regime [50].

A third niche for electric motors was the electric tram. Following its first commercial use in 1888, the electric tram diffused rapidly in the 1890s, becoming a proving ground for electric motors. With frequent stops and starts, rapid acceleration, and all-season weather exposure, this application showed that electric motors had become robust and strong.

This market niche also stimulated the development of larger electric motors with more horsepower [50]. These larger motors could subsequently be used in the niche of mediumrange industrial establishments to power machine tools and line shafts. By the early 1890s, industries such as printing and publishing, clothing and electrical machinery began using DC motors for such uses [53]. These industries were willing to accept the early problems of electric motors because they appreciated their specific operating characteristics: cleanliness, steady power, speed, and ease of control. In printing and textiles, for instance, the problem with traditional millwork was that the looms and presses farthest from the steam engine functioned erratically, which resulted in poorer quality work [50]. Electric motors for each shaft eliminated that problem, improving the speed of work and the quality of cloth and paper. These early applications of electric motors in factory production did not replace the traditional millwork. All shafts, countershafts, belts, pulleys and clutches remained [46]. The new technology was juxtaposed on the framework of the old system as an add-on. The steam engine was also maintained but was given a new function, namely, production of electricity. Fig. 6 schematically represents this change from direct drive to electric line shaft drive.

The first electric motors used direct current (DC) because that was all early electricity networks could provide. But when alternating current (AC) emerged for electric lighting, a standards battle erupted in the period between 1887 and 1895. By 1888, Westinghouse had developed the AC motor. The 'battle of systems' [54] created uncertainty for users, who did 


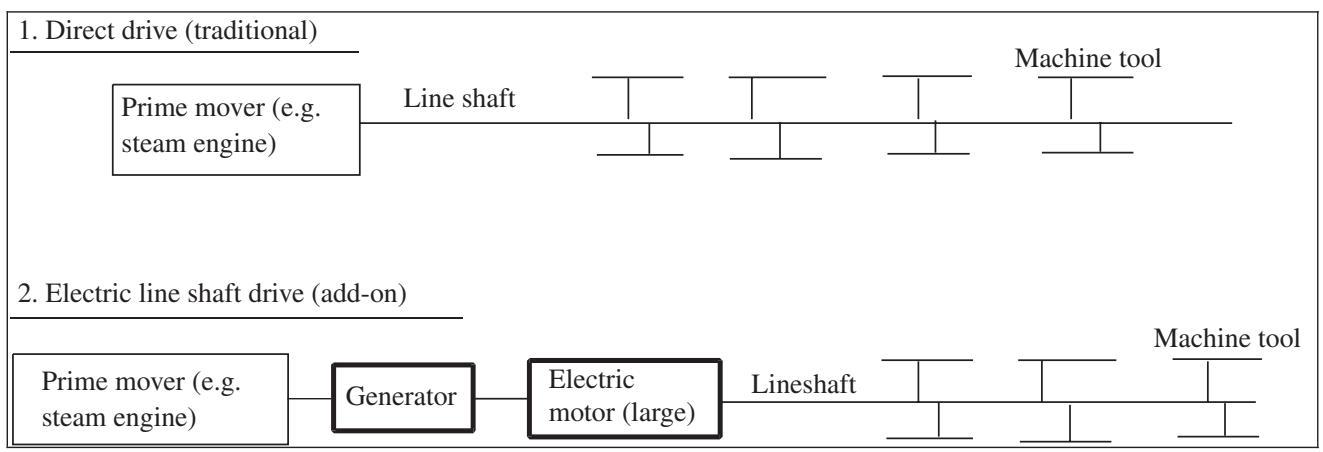

Fig. 6. From direct drive to electric line shaft drive. Source: based on [46, p. 353]

not know which kind of electric motor to adopt. But when $\mathrm{AC}$ won the battle by the mid1890 s, this stimulated the use of AC motors.

By 1900 , the early niches for electric motors amounted to about $5 \%$ of aggregate power used in American industry. This was enough to stimulate the emergence of a new industry - the electro-technical community, with dedicated actors and new trade and technical literature. Innovative activity focused on improving the dominant AC motor and bringing prices down. But demand from medium-size establishments remained small. Engineers often complained about the passive attitude of medium-size industry. For instance, in 1897 The Electrical Engineer declared: "There is no more conservative class of individuals than the owners of manufacturing establishments" ([48], p. 232). Yet to the small industrialist, the cost of power was not an urgent matter because it was a small part of total costs. Furthermore, sunk investments in the existing system contributed to an unwillingness to change. Electric utilities were not yet active in supporting the diffusion of electric motors because they saw themselves as lighting companies. Furthermore, the use of electric motors would probably not have created major markets for utilities because many factories produced their own electricity. By 1900, nearly $66 \%$ of electric power in US industry was supplied not by central stations but by isolated plants [48].

\subsection{Broader adoption of new elements and changing visions and attitudes (1900-1910)}

\subsubsection{Landscape-level developments}

At the landscape level, electricity became the cultural symbol of a new age. Promises about progress via electricity became part of the cultural repertoire, creating a positive context for electric motors.

Another landscape development was the rise of new industries. The manufacture of transportation equipment (including cars), electrical equipment, and petroleum, grew by $10 \%$ per year [46]. The further growth of factories exacerbated problems in materials handling and power distribution.

Another development was the emergence of the 'efficiency movement.' Efficiency became a widely observed principle in factory production, city building, and household management. 


\subsubsection{Regime-level developments}

During this period, the factory regime entered a period of flux. New solutions, pioneered in particular market niches, became more widely linked to problems in factory production. These solutions remained relatively separate from each other. They had not yet come together, linked up, and facilitated large-scale transformation. In retrospect, however, this was a period where many new elements were articulated and refined, paving the way for a regime shift to mass production. This was also a period in which industrial engineers developed new concepts and visions.

Materials handling remained a pressing problem in factories that assembled complex products like bicycles and automobiles. Many materials and parts were moved manually, which resulted in uneven supply to workstations. This meant that machine tools could not operate continuously. Earlier solutions such as electric cranes, monorails, and internal railways did not solve the problem, so industrial engineers began to look in other directions, such as more efficient use of space and positioning of machine tools to limit the distance of materials flows between workstations. Flow and throughput were increasingly important guiding principles. Industrial engineers realised that the arrangement of interior space influenced production efficiency. Hence, factory layout and design became a major focus of industrial engineering in the early decades of the 20 th century.

Industrial engineers felt that a new efficient production system needed a different factory to better facilitate production [40]. A major concern was to make the building fit production needs rather than organising production to fit the building. A growing number of engineers and architects agreed that machinery, labour, and materials should be organised more efficiently [55]. This was important because the number of machine tools continued to expand, creating more steps in production processes and more in-between flows of materials and parts. It also meant that factory space became more crowded with machinery.

In the early 20th century, the combination of steel and concrete offered some solutions to space and construction problems. Reinforced concrete helped transform factory buildings because of its strength, durability, and cheapness. It also had tremendous versatility because it could be moulded into virtually any shape or size. Reinforced concrete accomplished four improvements in factory construction:

(a) Reinforced concrete buildings were stronger, allowing heavy machinery to be safely installed on upper floors; it also reduced floor vibration from machines.

(b) It required fewer internal columns to carry the weight, thus saving space on the shop floor.

(c) The building could easily be made much larger.

(d) Reinforced concrete virtually eliminated factory fires which led to lower insurance rates [40].

Reinforced concrete also helped alleviate the lighting problem in factories. Because of its strength, reinforced concrete allowed buildings to be supported on internal columns, thus relieving the outside walls of bearing the weight. This created possibilities for enlarging the size of windows and improving light conditions in factories. 


\subsubsection{Broader adoption of electric motors}

The existing power distribution system (steam engines and millwork) constrained the more efficient use of space and positioning of machine tools that industrial engineers were advocating. These constraints were especially felt in rapidly growing industries such as transportation equipment, electrical equipment, and petroleum refining. This problem offered a window of opportunity for the diffusion of electric motors. Figs. 7 and 8 illustrate the shift from steam engines to electric motors in relative and absolute terms. Between 1899 and 1909 , the relative share of electric power in aggregate manufacturing power rose from $5 \%$ to $25 \%$. Fig. 8 shows that overall power consumption grew dramatically. This meant that the early growth of electric motors did not occur at the expense of steam engines, which also experienced growth in installed capacity until 1909.

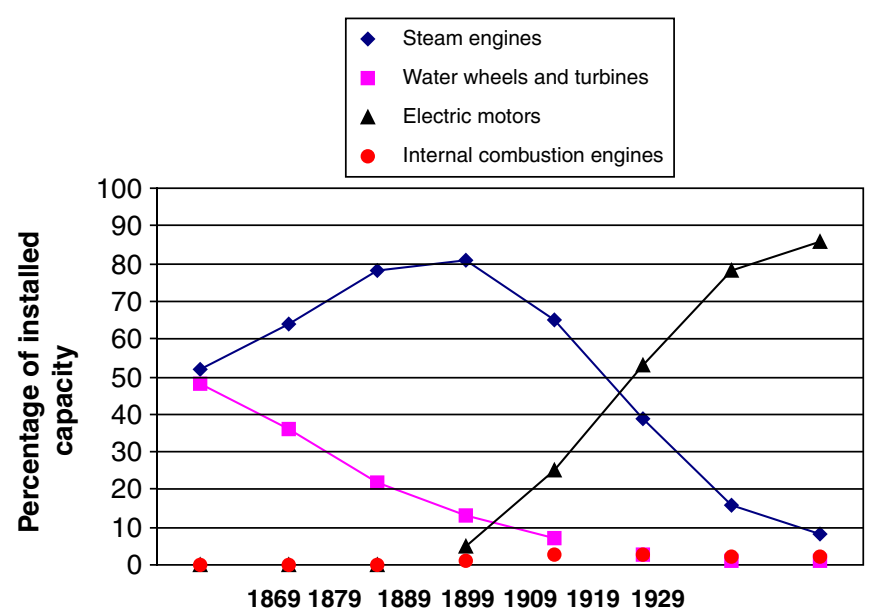

Fig. 7. Percentage of sources of mechanical drive in US manufacturing establishments. Source: based on data from [53]

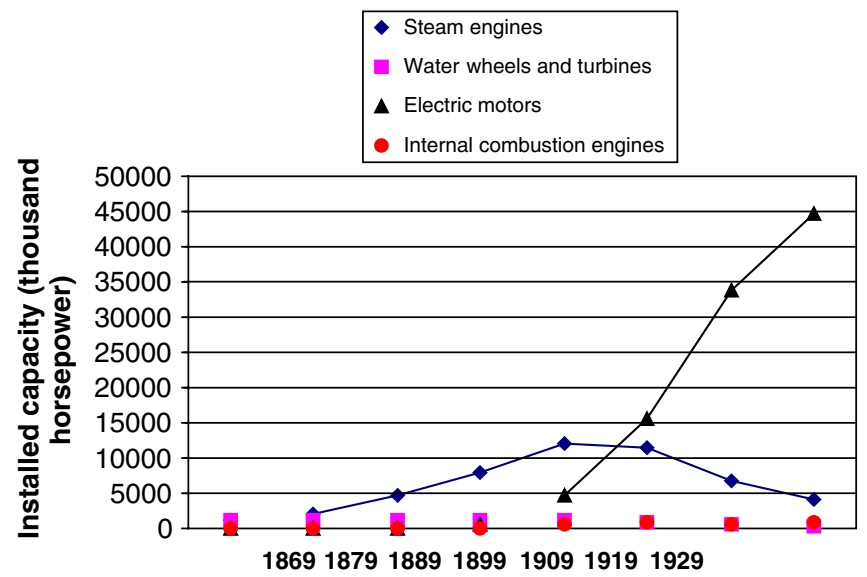

Fig. 8. Installed capacity of sources of mechanical drive in US manufacturing establishments. Source: based on data from [53] 
Table 2

Percentages of aggregate electric power of total capacity in different sectors

\begin{tabular}{|c|c|c|c|c|c|}
\hline & 1889 & 1899 & 1909 & 1919 & 1929 \\
\hline Food & 0.1 & 3.0 & 16.1 & 46.9 & 75.7 \\
\hline Beverages & 0.2 & 4.0 & 22.2 & 46.0 & 76.2 \\
\hline Tobacco & 1.5 & 17.8 & 49.3 & 79.7 & 97.1 \\
\hline Textiles & 0.2 & 3.4 & 24.3 & 57.6 & 85.2 \\
\hline Clothing (apparel) & 7.2 & 28.1 & 60.3 & 85.4 & 92.8 \\
\hline Lumber & - & 0.7 & 4.8 & 19.0 & 52.3 \\
\hline Furniture & 0.8 & 2.9 & 19.4 & 51.7 & 82.3 \\
\hline Paper & 0.1 & 0.7 & 11.7 & 34.3 & 69.9 \\
\hline Printing & 8.1 & 39.4 & 80.2 & 93.2 & 98.7 \\
\hline Chemicals & 0.2 & 10.0 & 41.0 & 65.0 & 83.0 \\
\hline Petroleum & - & 2.6 & 25.8 & 57.0 & 69.3 \\
\hline Rubber & 0.1 & 1.4 & 20.8 & 78.9 & 96.0 \\
\hline Leather & 1.2 & 8.2 & 35.2 & 73.9 & 86.1 \\
\hline Stone, clay, glass & - & 3.1 & 22.1 & 54.1 & 86.2 \\
\hline Primary metals & - & 2.7 & 16.1 & 36.7 & 63.6 \\
\hline Fabricated metals & 0.6 & 15.7 & 44.1 & 85.0 & 97.1 \\
\hline Non-electric machinery & 0.1 & 9.1 & 51.9 & 75.5 & 93.1 \\
\hline Electrical machinery & 8.5 & 49.2 & 87.6 & 96.0 & 90.3 \\
\hline Transportation equipment & 0.2 & 7.3 & 43.4 & 86.0 & 92.0 \\
\hline Instruments and miscellaneous & 1.4 & 7.8 & 41.0 & 72.1 & 93.9 \\
\hline All-manufacturing & 0.2 & 4.4 & 22.6 & 51.6 & 77.4 \\
\hline
\end{tabular}

Source: [53, p. 97).

Different industries adopted electric motors at different rates depending on their problems, perceptions, and incentives (see Table 2). In the early period, clothing, printing, electrical machinery, and tobacco were the leading industries. During the first decade of the 20th century, automobile production and chemistry became early adopters, boosting the diffusion of electric motors because these industries grew so rapidly.

The leading industries provided space to learn about integrating electric motors into power distribution systems. As new possibilities were discovered, manufacturing plants were often redesigned to better use electric power [35]. In American manufacturing, the introduction of electric motors occurred via a stepwise process of hybridisation and gradual transformation. Four phases can be distinguished[46]:

1. Direct drive (traditional system). Steam engines are mechanically linked to machine tools via shafts, countershafts, belts, pulleys, etc.

2. Electric line shaft drive. An electric motor and generator were added to the existing system (add-on). The existing steam engine was used to generate electricty, which powered a single electric motor, which then drove the millwork.

3. Electric group drive (Fig. 9). The traditional millwork was divided into drive smaller groups of machines that were powered by an electric motor.

4. Electric unit drive (Fig. 9). Each machine was powered by its own electric motor. The traditional millwork was replaced by electric wires. 

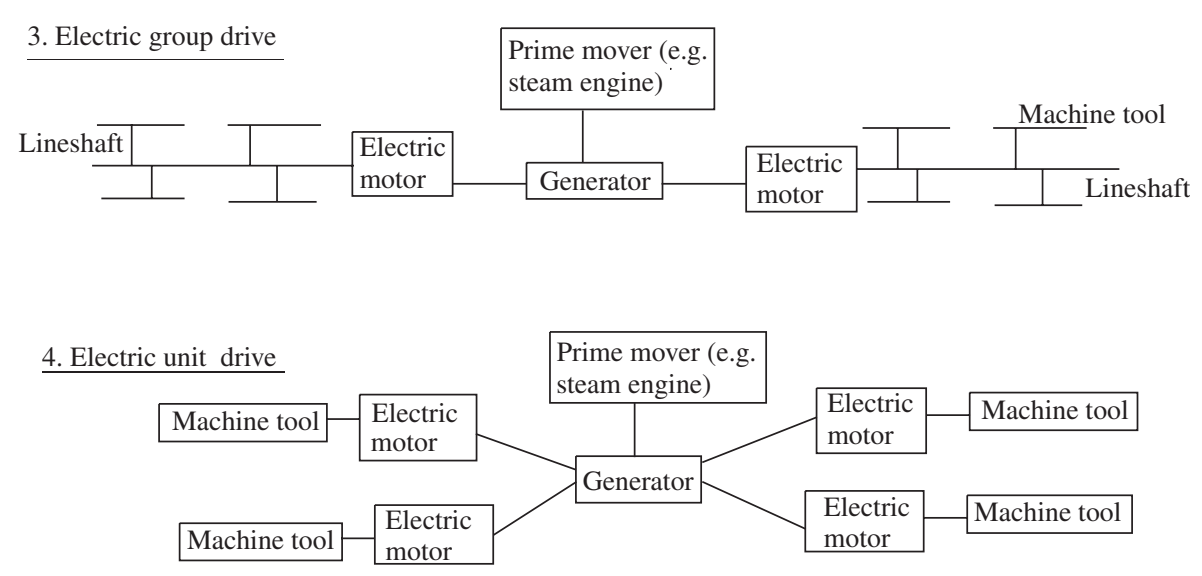

Fig. 9. Electric group drive and unit drive. Source: based on [46, p. 353]

The experiences of leading industries were widely discussed in industrial engineering journals. The first application of group-drive electric motors was in the General Electric Company plant in New York in 1892. It was found that group drive diminished the amount of dust and dirt because part of the millwork was no longer needed. When motors were mounted to the ceiling, they also saved floor space. Group drive offered more flexibility in locating machinery, thus making it easier to reorganise the sequence of manufacturing operations. Group drive also improved the energy efficiency of manufacturing because it reduced friction losses. In addition, groups of machines could be operated independently when needed. Typical savings in the amount of coal used were between $20 \%$ and $25 \%$ [46]. These direct cost advantages were the main reason for the adoption of group drive.

There were also discussions about unit drive because some industrial engineers saw possibilities to completely abandon traditional millwork. In the late 1890s, they argued that unit-drive electric motors had the potential to free up and restructure the entire production system. Although the industrial engineers' proposed visions had the potential to transform industry, there was little concrete experience to back up those visions. Implementation of unit drive was limited because electric motors were still expensive, making it costly to fit each machine with its own motor. Before 1905, unit drive was only used for the largest machines (e.g., cranes, hoisting appliances, elevators). Fig. 10 shows the gradual and overlapping shifts in the different phases in the application of electric motors. These shifts were not automatic but involved learning about the technical possibilities and benefits of electric motors. In the early phases, direct cost advantages, such as lower fuel costs, were the main driver for adoption. In later phases unit drive enabled important indirect advantages, which led to large-scale transformations.

The first decade of the 20th century also witnessed changes in perception and strategies among electric utilities. New concepts in electricity management (e.g., load factor, diversification) made utility managers more willing to advocate the use of electric motors. Reliable electric metres were developed, electricity rates for large power users were reduced, and efforts were made to educate customers [48]. In 1906, central-station utilities began vigorous advertising campaigns in support of electric motors. The self-perception of 


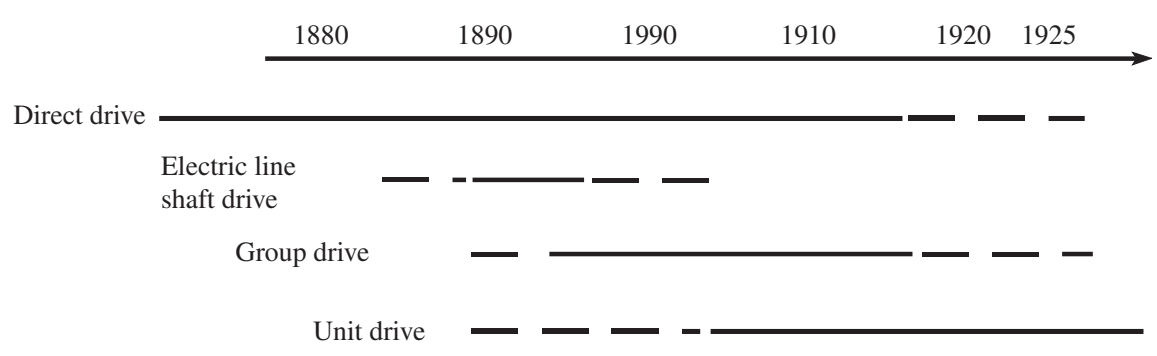

Fig. 10. Chronology of methods for driving machinery in US industry. Source: based on [46, p. 354]

utilities changed from a lighting industry to a general electric-energy supplier. Reduced prices for electricity made it increasingly attractive for factories to switch to electric drive and do away with their steam engines. However, this shift occurred slowly, as many factory owners did not want to lose sunk investments in existing systems. Furthermore, they often postponed adoption decisions because they anticipated continual improvements in electric motors.

\subsection{The emergence of mass production (1910-1930)}

The previous period (1900-1910) was a period of flux, in which new elements and solutions were created and refined in reaction to specific problems. In the 1910s and 1920s the factory production regime was dramatically transformed because several solutions and developments from the previous period were combined. Metaphorically, the new elements crystallised and gelled into a new configuration. The electric motor was an important stimulus for this process, especially as new opportunities for unit drive were explored.

The new mass-production regime was first developed in the automobile industry, which experienced rapid growth during this period. This section describes the general shift toward electric motors and new factory buildings, and then discusses the dramatic transformation pioneered by the automobile industry.

\subsubsection{New elements set the stage for reconfiguration}

Between 1909 and 1929, the diffusion of electric motors increased from $25 \%$ to $75 \%$ (Fig. 7). Fig. 8 showed that overall power consumption grew dramatically in this period, owing to a strong increase in the capital/labour ratio. More machines were introduced into the production process, requiring more energy. Fig. 10 shows that this period was also characterised by a shift toward unit drive. Factory owners gradually abandoned steam engines and millwork in favor of then best-practice: unit drive. This was accompanied by a gradual shift from self-generation of electricity in factories to purchased electricity. In 1900 , around $66 \%$ of electric power in US manufacturing was self-generated; in 1920 this was $43 \%$, and by 1929 it had declined to 34\% [53]. Electricity use in factories was a booming market for electric utilities. Recognising the potential of this market, utilities encouraged the diffusion of electric motors by embarking on advertising campaigns and offering cheaper rates to large factories. The decline of self-purchased power relieved factories of the capital, labour, and fuel expenses involved in operating and maintaining steam engines and generators. 
Between 1905 and 1915, unit drive became the standard way of using electric motors in manufacturing. One driver was technical improvements regarding the range of speed for electric motors, widening their applicability to high-performance machine tools [48]. Another driver was the gradual realisation that indirect gains might be far larger than direct economies in equipment, maintenance, and fuel. The most important indirect advantage of unit drive was that powering individual machines made it possible to do away with the intricate millwork. Machine tools were no longer fixed to line shafts but could be placed according to the work sequence. This created new opportunities for factory layouts and machine arrangements, making better use of floor space and minimising material flows between work stations.

But unit drive also enabled other indirect advantages [36]. The removal of millwork eliminated labour requirements for oiling and maintaining the belt-drive apparatus. Machine control was improved and the problem of belt slippage eliminated. If one machine broke down or had to be retrofitted, this no longer meant shutting down the entire power system. Removal of the belting resulted in better light distribution and cleaner factories with less dust and grease in the air. Electric light and daylight could better reach the shop floor. The new power system also reduced the fire risk (and insurance premiums) by eliminating openings in the floors through which the old shafting passed. The elimination of belts and shafts also reduced the risk of injuries to workers.

The gradual recognition of these indirect savings changed the perception of electric motors, which came to be seen as 'levers to increase production,' enabling further changes and transformations in the factory system [46]. Electric motors and unit drive opened vast possibilities for the industrial engineer, and many industries eagerly experimented with them, in particular the automobile industry.

Stimulated by the opportunities of steel and reinforced concrete, industrial engineers also turned their attention to factory buildings, developing new ideas about factory size, shape, and number of floors. Some argued for single-story factories because they were easy to build with steel and reinforced concrete, and could span large distances, creating more open space. Single-story factories permitted linear layouts, which facilitated more efficient materials handling and flexible reconfiguration of machine placement. But single-story factories also required more ground and sophisticated materials-handling technologies. When refinement of the assembly line provided better materials handling, single-story buildings became more widespread in the 1920s. Another advantage of reinforced concrete and steel was that window areas could be enlarged, opening the way to the 'daylight factory.' Ford's Highland Park Plant (1910), the 'Crystal Palace,' was one of the first daylight factories [40].

\subsubsection{Automobile industry as niche for new system}

In this context of dynamic change, the automobile industry was where an entirely new way of factory production was pioneered: mass production on the assembly line. The automobile industry had resources for experimentation because of the dramatic growth of car sales in America, in particular the Ford Model $\mathrm{T}$, which had become the dominant design. In 1910, 485,300 people bought cars; by 1920 the number had risen to more than eight million, and in 1930 it was over 23 million. Such rapid market growth generated resources for building new plants and encouraged experimentation with new production systems. The Ford factory did not pioneer mass production from scratch. Rather, their innovation consisted of combining and further developing elements and trends that had 
already been pioneered previously. These elements and trends included: (a) special-purpose machine tools, (b) interchangeable parts, (c) subdivisions of labour, (d) continuous moving conveyor line, (e) sequential ordering of machines, and (f) the use of electric motors.

Early in the 20th century, automobile manufacturing became one of largest users of machine tools. Automobiles consist of many specialised, precision-finished, hardened-steel parts that were often manufactured by the car factories themselves. The requirements of automobile production generated innovations and improvements across a wide range of machine tools - for drilling and tapping, for milling, for lathe work, etc. [47]. Specialpurpose machine tools, already used in sewing machine and bicycle manufacturing, were further developed. For instance, sheet-metal stamping was further developed in the automobile industry, as was electric-resistance welding. The practice in which each machine performed a single function enabled high standards of precision. Electric motors allowed reliable standardisation of speeds and stimulated the functioning of machine tools.

Ford clearly understood the importance of achieving parts interchangeability. If precision parts could be created, it would facilitate rapid assembly, since precision parts needed no adjusting or fitting. Improvements in machine-tool accuracy further refined this practice. Ford engineers placed accuracy at the top of the list of fixture and machine-tool requirements, and they built many special machines for Model $\mathrm{T}$ production. This accuracy was the rock upon which Ford's mass production was based [39].

Ford also pursued the trend of increasing division of labour. Jobs were further subdivided into smaller operations that could be done with machine tools by unskilled labour. Thus, the diffusion of machine tools and subdivision of labour went hand in hand. From time studies conducted by industrial engineers such as Taylor, it was concluded that overall efficiency improved if workers performed the same small task over and over. These engineers saw human workers as an unreliable factor in production, with the potential to slow down work when supervisors were not paying attention. Hence, industrial engineers argued for more visibility and control over workers.

Materials handling remained a problem in early car manufacturing. At assembly stations, men worked at open workbenches, with parts bins placed in the middle of the benches, each man assembling a component. Final assembly of the car was still static in 1910. The car frame rested on wooden assembly horses or stands while assembly teams moved down the row of chassis [40]. Components and assemblies-in-process had to travel between workstations to the final assembly area, so there was constant pushing, shoving, and carting of materials from one workstation to the next (see Fig. 11). This manual materials handling was cumbersome, especially as buildings grew larger and products more complex. It was also unpredictable and difficult for managers to control. Hence, plant layout and materials handling were high on the agenda of problems to be solved by Ford engineers.

In the Highland Park factory, Ford engineers began to think about how the factory could be laid out based on the sequence of the production process. Industrial engineers made operations sheets and tried to rearrange machine tools in a sequential manner. This was made possible by electric motors, which eliminated the traditional millwork and created more flexibility.

In 1913, Ford allowed his engineers to undertake extensive experiments in the factory, which led to "one of the most remarkable sustained bursts of technical creativity in history" ([56], p. 150). The crucial experiment was the assembly line, a new way of materials handling that had already been pioneered in meatpacking, flour milling, brewing 


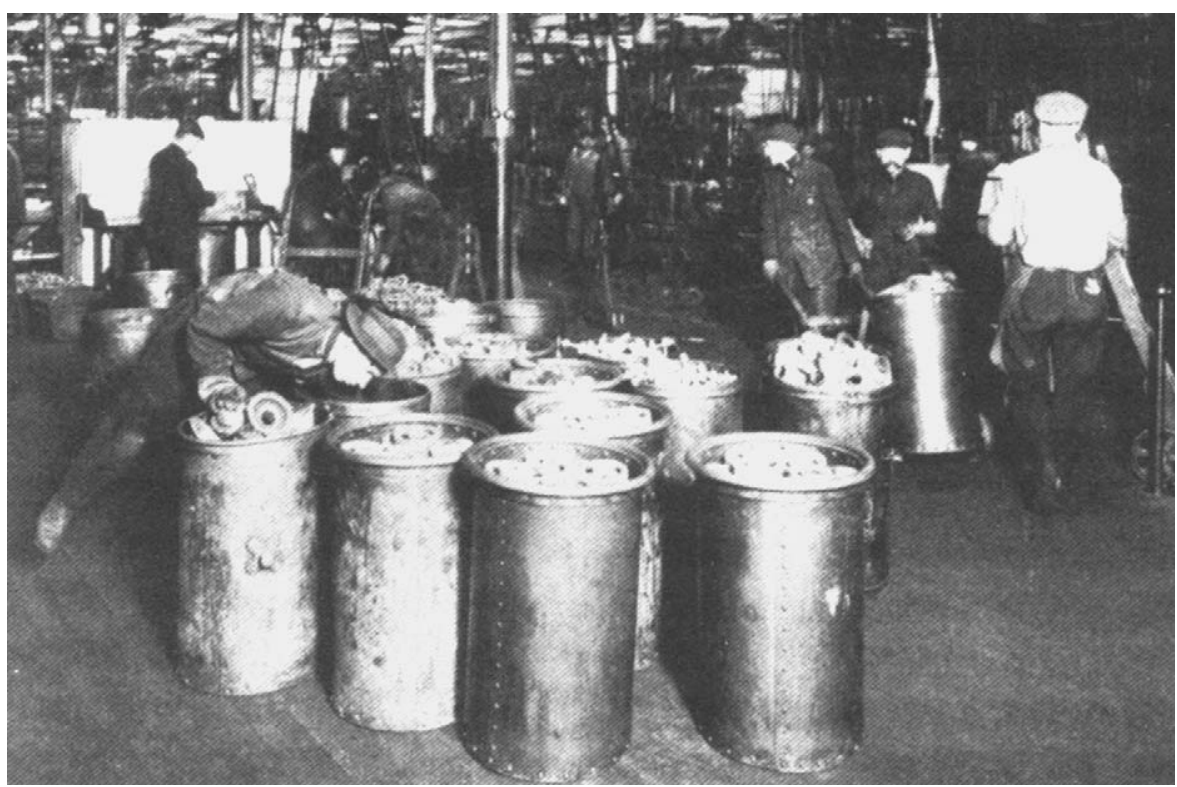

Fig. 11. Pushers and shovers moving part barrels, November 1916. Source: [40, p. 114]

industry, and food canning [39]. Electric motors facilitated the use of conveyor lines because they operated the belts, chains, and other devices at reliable and stable speeds. Special-purpose machine tools, the division of labour, interchangeable parts, and electric motors all came together in the assembly line. On April 1, 1913, experiments began with the first moving assembly line for manufacturing flywheel magnetos. No longer did men stand at individual workbenches, each putting together an entire flywheel magneto assembly from the many parts. Workers now put one specific part into the assembly or started a few nuts and then pushed the flywheel down the row to the next worker. Each worker repeated his assigned process over and over again (see Fig. 12). The experiment was a great success in terms of productivity. On the first day, productivity increased from three magnetos per hour per person to 4.6 magnetos/h/person [39]. In the following months, productivity was further raised by additional innovations, such as raising the height of the line, reducing the number of workers, moving the flywheels with a continuous chain.

Because productivity increased dramatically, the principle was also applied to other assembly operations, such as engines, chassis, transmissions, and magneto coils. Within a year, virtually every assembly operation had been put on a moving-line basis. Small streams flowed into larger streams, which flowed into great rivers. The key was to orchestrate and integrate the various assembly lines in terms of speed, input, and output. Elaborate motion and time studies were done to determine how fast and how long workers could keep up the pace.

On the other hand, workers' freedom became limited as the conveyor system determined the work pace. The assembly line thus changed relations between management and workers, allowing management to control the pace of work through the speed of the assembly lines [50]. This new work practice created considerable strain on labourers, 


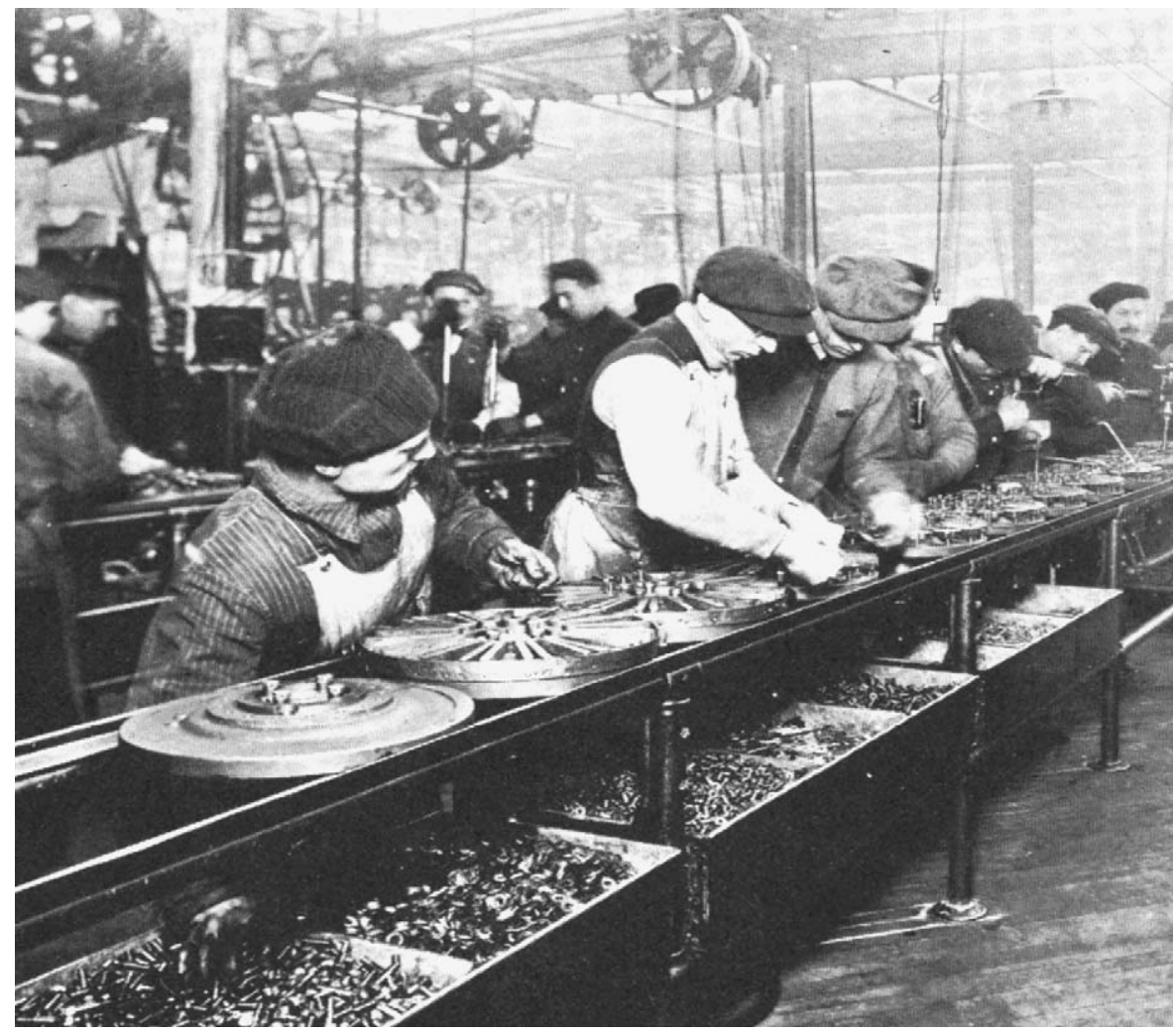

Fig. 12. The first magneto assembly line, 1913. Source: [39, p. 246]

resulting in higher turnover rates. Many workers quit their job because they could not tolerate the stress, but others were willing to take their place, even if just for a few months.

\subsubsection{Diffusion and dissemination}

While Highland Park was the first 'niche' for the assembly line, it came into full realisation at the River Rouge plant, which opened in 1920. This was a massive plant with multiple, huge, single-story buildings. Their shape and size were determined by the production processes, not constrained by building materials, power distribution, or materials handling. River Rouge shifted to single-story buildings because they were less costly to build and provided more manufacturing floor space. Because conveyor lines, monorails, and cranes had greatly improved, engineers no longer had to worry about moving parts and materials across a wide floor space [40].

The River Rouge plant introduced the modern factory to the world, combining rational factory planning with modern production, power, and construction technology. Mechanised systems for materials handling, automated machinery, and the elimination of belts for power transmission freed engineers to lay out the shop floor in the most efficient manner. That freedom, coupled with reinforced concrete and steel construction, opened vast possibilities for factory design. River Rouge represented the direction of future development for modern industry, in building style and production methods. 
The plant achieved mythic stature as the ultimate expression of Fordism, the triumph of rational efficiency. Somewhere between 100,000 and 500,000 visitors toured "the Rouge" each year in the late 1920s making it arguably the world's largest working exhibit of technical progress [56].

The assembly line was widely imitated in other large industries. But not all sectors were as profoundly transformed as the automobile sector. The restructuring of manufacturing was less radical in industries such as printing and paper, where firms chose selectively from a range of possible factory layouts and design features [55]. Nevertheless, Fordism became a world-wide symbol representing a new technocratic and efficient order.

\section{Analysis}

The transformation of American factory production and the emergence of mass production are generally believed to have been caused by the replacement of steam engines by electric motors. Although the electric motor was an important element in the transformation, the case study presented here shows that the transformation came about because many different developments linked up and reinforced each other. Several external landscape developments played a role: the creation of rail networks; the emergence of a national market; population growth, economic growth, and rising buying power; the rise of engineers; electricity as pervasive technology and symbol of modernity; and the Efficiency Movement.

At the regime level, two clusters of processes drove developments: (1) division of labour, mechanisation, and the development and application of machine tools, and (2) scale expansion and the rise of big business. However, these processes also led to problems with machine arrangements, materials handling, lighting, power generation, and power distribution. These problems created windows of opportunity for many innovations that initially emerged in specific niches and were subsequently adopted in the regime, e.g., electric cranes, monorails, conveyor belts, gas engines, hot-air engines, steam distribution, water motors, hydraulic power, and electric motors. Some of these niche innovations failed (e.g., water motors, hydraulic power, hot-air engines), while others were moderately successful in large factories (gas engines). Also new materials, such as steel and reinforced concrete, emerged and were adopted into the regime.

It was the combination of external landscape pressures, ongoing regime developments, and the adoption of many niche elements that resulted in the reconfiguration of factory production. So the case study demonstrated the usefulness of the MLP and its emphasis on alignments between landscape, regime, and niche developments (see Fig. 13 for a schematic representation).

The case study showed that the transition was not caused by one breakthrough innovation, but by multiple niche innovations that were adopted into the regime (rather than having competitive relations with it). Electric motors, for instance, entered the regime for add-on functions such as electric crane and fan. And specific materials-handling innovations, such as conveyor belts, which were initially developed in particular niches (can making, meat packing), entered the regime as materials-handling problems increased. Furthermore, many incremental innovations were involved, including stepwise changes in machine tools, motors, and buildings. So the second Industrial Revolution grew out of the accumulation of multiple bigger and smaller innovations. 


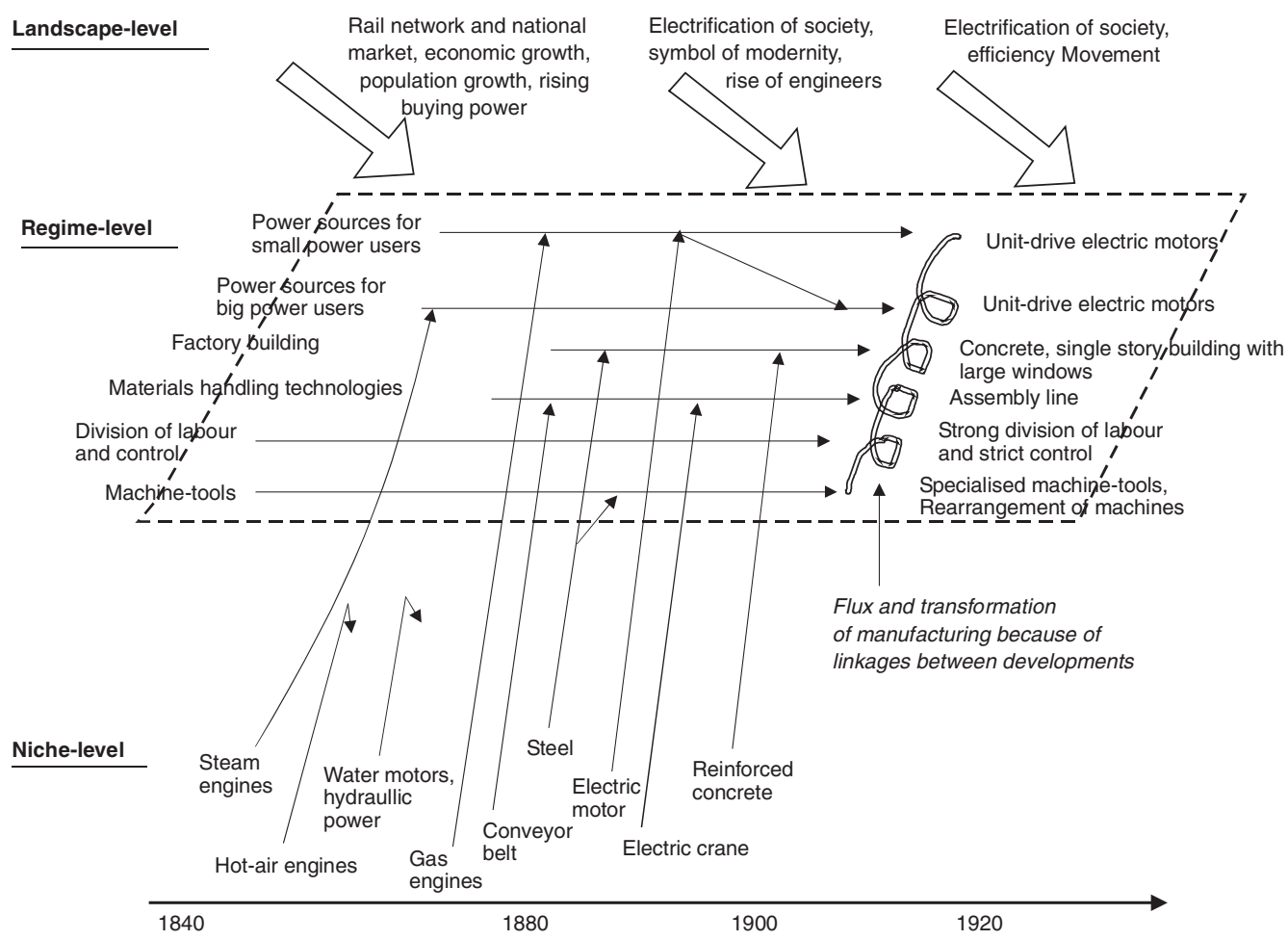

Fig. 13. Reconfiguration dynamics in the transformation of factory production.

More generally, it can be concluded that the reconfiguration pathway consisted of three phases. First, problems increased in the factory production regime, driven by mechanisation and scale increase. Meanwhile, innovations were developed in particular sectors, which acted as nurturing niches. Second, multiple niche innovations were adopted in the regime as problems increased. This took the form of add-on or component replacement, with the regime maintaining its basic architecture. The third step was a complete reconfiguration and creation of a new system. Two processes were important in this reconfiguration. One process was improvement in electric motors and learning about their potential advantages. The evolution from direct drive to line-shaft drive to group drive to unit drive was accompanied by a shift from direct cost advantages to more indirect flexibility and rearrangement advantages. Although electric motors were initially adopted to resolve specific problems, they became catalysts for wider change. The second process was aligning and linking many elements that had been developed previously, such as special-purpose machine tools, interchangeable parts, conveyor lines, sequential ordering of machines, electric motors, and reinforced concrete and steel. New combinations of these elements allowed the creation of a new system architecture.

Thus, mass production was the last step in a much longer transformation and reconfiguration process. Fordism was built on the many changes that preceded it, and the new production regime grew out of the old one. This dynamic is an important characteristic of the reconfiguration pathway. The literature on technological substitutions 
and discontinuities emphasises how incumbents are replaced by newcomers and outsiders. But in reconfigurations the incumbent regime actors enact the transition and do not disappear. The case study showed that the regime was not weak and eroded, but experienced growth and expansion. Regime problems that occurred took the form of 'reverse salients' [24], i.e., internal problems that occur as a system expands and then fall behind other changes. Because these internal problems increasingly functioned as a straightjacket, they were high on the agenda of problems needing solution. That is why incumbents allocated resources to innovative activities that might alleviate problems. So the transition did not come about because outsiders criticised the regime for certain negative externalities (as is currently the case with environmental problems). Instead, internal problems drove the transition.

One qualification to the previous point is that the new mass production system was pioneered not in an 'old' but a 'new' industry, specifically autos. So in that sense newcomers were important. A second qualification is that there was some debate about possible negative externalities, in particular concerns that the rise of big business would destroy many small artisan workshops. But these debates about labour and small firms took place among journalists and statesmen, and had little effect on the transition. As a result, there was little societal opposition against the fundamental direction of developments. This scenario was somewhat different in European countries with more developed labour unions and socialist political parties [43]. Debates in America were less about fundamental direction than about speed and technical paths, and the main tension was between industrial engineers and factory owners. ${ }^{2}$

One specific regime characteristic - its variety of niches and application domainsfacilitated the reconfiguration pathway. Although factory production was characterised as a regime, there were many different industrial sectors, with specific challenges, problems, and competencies. This variety was beneficial for the initial emergence of novelties in specific sectors (interchangeable parts in arms making, conveyor belts in canning and meat packing, special purpose machine tools in bicycle and sewing machine industries, electric motors in printing, publishing and clothing). These sectors acted as niches from which innovations could later diffuse to other sectors. So this high variability had positive effects on the emergence of novelty. It also gave rise to many instances of spillover and niche accumulation. This pattern was obvious with electricity, which first appeared in large factories in the form of electric lighting. Then electric motors took on additional functions in factories, such as powering fans and electric cranes. Electric motors further developed in the niche of electric trams, and then gradually re-entered factories to power machines, first as add-ons placed between steam engines and line shafts (in printing and publishing). Thereafter, they evolved to a mixture of old and new technologies (group drive) in the electro-technical industry. Eventually electric motors were used as unit drives, first in large industries, later more widespread. As experience with unit drives grew, all kinds of followon effects and qualitative advantages were identified, enabling broader reconfiguration. Electric power thus entered factories through a stepwise process of niche accumulation. It began small but mushroomed to encompass more functions and triggered further changes.

\footnotetext{
${ }^{2}$ Industrial engineers were change agents who developed visions about major restructuring using unit-drive electric motors and other new innovations. But factory owners postponed rapid implementation because they wanted to write off sunk investments and wait for cost improvements in electric motors.
} 


\section{Conclusions}

The common view of transitions and system changes is technological substitution, with one core technology replacing another, followed by social-political adjustment and changes in peripheral components. This is an important dynamic, but one that is found primarily in sectors that are organised around a dominant technology. For sectors without a clear core technology, this article has described reconfiguration as a different transition pathway. Refinements were made in a MLP to conceptualise this transition path. New elements are developed in particular niches and subsequently adopted in existing regimes to solve specific problems. These new elements may subsequently trigger further regime transformations as more is learned about them and as external landscape changes occur. These transformations then create opportunities for the adoption of other niche innovations, which can create new combinations with other elements. The transition dynamic is not that of one new element breaking through and changing the system, but of many small changes accumulating over time to become major reconfigurations.

This reconfiguration perspective was illustrated with a historical case study - the transformation of American factory production and the emergence of mass production. The case study offered a good example of the reconfiguration perspective, and it is concluded that the perspective is plausible. It is expected that this perspective is also relevant for transitions in other domains that include multiple technologies, such as retailing, hospitals, and agriculture.

\section{Acknowledgement}

I gratefully acknowledge financial support from the Dutch Knowledge Network on System Innovation (KSI).

\section{References}

[1] Cooper AC, Schendel D. Strategic responses to technological threats. Bus Horiz 1976:61-9.

[2] Tushman M, Anderson P. Technological discontinuities and organization environments. Admin Sci Q 1986;31:439-65.

[3] Anderson P, Tushman M. Technological discontinuities and dominant designs. A cyclical model of technological change. Admin Sci Q 1990;35:604-33.

[4] Christensen C. The innovator's dilemma. When new technologies cause great firms to fail. Cambridge, MA: Harvard Business School Press; 1997.

[5] Grübler A, Nakićenović N. Evolution of transport systems. Past and future. Research report-91-8. Laxenburg: International Institute for Applied Systems Analysis; 1991

[6] Abernathy WJ, Utterback J. Patterns of industrial innovation. Technol Rev 1978;50:41-7.

[7] Suarez FF, Utterback JM. Dominant designs and the survival of firms. Strat Manage J 1995;16:415-30.

[8] Klepper S. Entry, exit, growth, and innovation over the product life cycle. Am Econ Rev 1996;86(3):562-83.

[9] Henderson RM, Clark KB. Architectural innovation. The reconfiguration of existing product technologies and the failure of established firms. Admin Sci Q 1990;35:9-30.

[10] Tushman ML, Rosenkopf L. Organizational determinants of technological change. Towards a sociology of technical evolution. In: Cummings LL, Staw BM, editors. Research in organizational behavior, vol. 14. Greenwich, CT: JAI Press; 1992. p. 311-47.

[11] Tushman ML, Murmann JP. Dominant designs, technology cycles, and organizational outcomes. Res Org Behav 1998;20:240.

[12] Gersick CJG. Revolutionary change theories. A multi-level exploration of the punctuated equilibrium paradigm. Acad Manage Rev 1991;16(1):10-36. 
[13] Geels FW. Co-evolution of technology and society. The multi-level perspective and a case study, the transition in water supply and personal hygiene in the Netherlands (1850-1930). Technol Soc 2005;27(3): 363-97.

[14] Rip A, Kemp R. Technological change. In: Rayner S, Malone EL, editors. Human choice and climate change. Columbus, OH: Battelle Press; 1998. p. 327-99.

[15] Geels FW. Technological transitions as evolutionary reconfiguration processes. A multi-level perspective and a case-study. Res Pol 2002;31(8/9):1257-74.

[16] Geels FW. From sectoral systems of innovation to socio-technical systems. Insights about dynamics and change from sociology and institutional theory. Res Pol 2004;33(5):897-920.

[17] Geels FW. Technological transitions and system innovations. A co-evolutionary and socio-technical analysis. Cheltenham: Edward Elgar; 2005.

[18] Elzen B, Geels FW, Green K, editors. System innovation and the transition to sustainability: theory, evidence and policy. Cheltenham: Edward Elgar; 2004.

[19] Schot J, Hoogma R, Elzen B. Strategies for shifting technological systems. The case of the automobile system. Futures 1994;26:1060-76.

[20] Kemp R, Schot J, Hoogma R. Regime shifts to sustainability through processes of niche formation. The approach of strategic niche management. Technol Anal Strat Manage 1998;10:175-96.

[21] Hoogma R, Kemp R, Schot J, Truffer B. Experimenting for sustainable transport. The approach of strategic niche management. London and New York: Spon Press; 2002.

[22] Belz F-M. A transition towards sustainability in the Swiss agri-food chain (1970-2000). Using and improving the multi-level perspective. In: Elzen B, Geels FW, Green K, editors. System innovation and the transition to sustainability. Theory, evidence and policy. Cheltenham: Edward Elgar; 2004. p. 97-113.

[23] Van Driel H, Schot J. Radical innovation as a multi-level process. Introducing floating grain elevators in the port of Rotterdam. Technol Cult 2005;46(1):51-76.

[24] Hughes TP. The evolution of large technological systems. In: Bijker WE, Hughes TP, Pinch T, editors. The social construction of technological systems. New directions in the sociology and history of technology. Cambridge, MA: MIT Press; 1987. p. 51-82.

[25] Von Meier A. Integrating supple technologies into utility power systems. Possibilities for reconfiguration. In: Summerton J, editor. Changing large technical systems. Oxford: Westview Press; 1994. p. 211-30.

[26] Grundmann R. Car traffic at the crossroads. New technologies for cars, traffic systems, and their interlocking. In: Summerton J, editor. Changing large technical systems. Oxford: Westview Press; 1994. p. $265-89$.

[27] Latour B. Society is technology made durable. In: Law J, editor. A sociology of monsters. Essays on power, technology and domination. London: Routledge; 1991. p. 103-31.

[28] Latour B. La clef de Berlin et autres lecons d'un amateur de sciences. Paris: Editions la Decouverte, 1993.

[29] Sanchez R, Mahoney JT. Modularity, flexibility, and knowledge management in product and organization design. Strat Manage J 1996;17:63-76.

[30] Baldwin CY, Clark KB. Managing in an age of modularity. Harvard Bus Rev 1997(September-October):84-93.

[31] Sabel C, Zeitlin J. Historical alternatives to mass production. Past Present 1985;108:133-76.

[32] Sabel CF, Zeitlin J, editors. World of possibilities. Flexibility and mass production in Western industrialization. New York: Cambridge University Press; 1997.

[33] Scranton P. Endless novelty. Specialty production and American industrialization 1865-1925. Princeton: Princeton University Press; 1997.

[34] Chandler Jr AD. The visible hand. The managerial revolution in American business. Cambridge, MA: Belknap Press; 1977.

[35] David PA. The dynamo and the computer. An historical perspective on the modern productivity paradox. Am Econ Rev 1990;80(1):355-61.

[36] David PA. Computer and dynamo. The modern productivity paradox in a not-too-distant mirror. Technology and productivity: the challenge for economic policy. Paris: OECD; 1991. p. 315-47.

[37] Sonenblum S. Electrification and productivity growth in manufacturing. In: Schurr S, editor. Electricity in the American economy. New York: Greenwood Press; 1990. p. 325-39.

[38] Goldfarb B. Adoption of general purpose technologies. Understanding adoption patterns in the electrification of US manufacturing, 1880-1930. Social science research network electronic library; 2001. 
[39] Hounshell DA. From the American system to mass production, 1800-1932. The development of manufacturing technology in the United States. Baltimore and London: The John Hopkins University Press; 1984.

[40] Biggs L. The rational factory. Architecture, technology and work in America's age of mass production. Baltimore and London: The John Hopkins University Press; 1996.

[41] Habakkuk HJ. American and British technology in the nineteenth century. Cambridge: Cambridge University Press; 1962.

[42] Faragher JM, Buhle MJ, Czitrom D, Armitage SH. Out of many. A history of the American people. New Jersey: Prentice Hall; 1997.

[43] Van Lente D. Techniek en ideologie. Opvattingen over de maatschappelijke betekenis van technische vernieuwingen in Nederland, 1850-1920. Groningen: Wolters-Noordhof; 1988.

[44] Banham R. A concrete Atlantis. US industrial buildings and european modern architecture, 1900-1925. Cambridge, MA: MIT Press; 1986.

[45] Van Cappelle P. De elektriciteit, hare voortbrenging en hare toepassingen in de industrie en het maatschappelijk verkeer. Leiden: Sijthoff; 1908.

[46] Devine Jr. W. From shafts to wires. Historical perspective on electrification. J Econ Hist 1983;43(2):347-72.

[47] Rosenberg N. Technological change in the machine tool industry, 1840-1910. In: Rosenberg N, editor. Perspectives on technology. Cambridge: Cambridge University Press; 1976. p. 9-31.

[48] Hunter LC, Bryant LL. A history of industrial power in the United States, 1780-1930. The transmission of power. Cambridge, MA: MIT Press; 1991.

[49] Bowers B. Electricity. In: McNeil I, editor. An encyclopedia of the history of technology. London and New York: Routledge; 1995. p. 350-87.

[50] Nye D. Electrifying America. Social meanings of a new technology. Cambridge, MA: MIT Press; 1990.

[51] Rosenberg N. Inside the black box. Technology and economics. Cambridge: Cambridge University Press; 1982.

[52] Freeman C, Louça F. As time goes by. From the industrial revolutions to the information revolution. Oxford: Oxford University Press; 2001.

[53] DuBoff R. Electric power in American manufacturing. New York: Arno Press; 1979.

[54] David PA. Heroes, herds, and hysteresis in technological history. Thomas Edison and the 'battle of the systems' reconsidered. Ind Corporate Change 1992;1:129-80.

[55] Lewis R. Redesigning the workplace. The North American factory in the interwar period. Technol Cult 2001;42:665-84.

[56] Staudenmaier J. Henry Ford's relationship to "Fordism" Ambiguity as a modality of technological resistance. In: Bauer M, editor. Resistance to new technology. Nuclear power, information technology, and biotechnology. Cambridge: Cambridge University Press; 1995. p. 147-64.

Dr. Frank Geels is Assistant Professor in the Department of Technology Management at Eindhoven University of Technology, the Netherlands. His main research topics are technological transitions and system innovations. He studies this topic with a multi-disciplinary approach, using insights from sociology of technology, innovation studies, history of technology, and evolutionary economics. The conceptual work is grounded in historical case studies on transitions in the past. He has also explored possible future transitions in transport and energy, using socio-technical scenarios as a new exploration methodology. 